\title{
Nanostructured Manganese Oxide Supported on Carbon Nanotubes for Electrocatalytic Water Splitting
}

\author{
K. Mette, ${ }^{[a]}$ A. Bergmann, ${ }^{[b]}$ J.-P. Tessonnier, ${ }^{* a, c]}$ M. Hävecker, ${ }^{[a, d]}$ L. Yao, ${ }^{[a]}$ T. Ressler, ${ }^{[\mathrm{e}]}$ \\ R.Schlögl,${ }^{[a]}$ P. Strasser, ${ }^{*[b]}$ M. Behrens ${ }^{*[a]}$
}

${ }^{a}$ Fritz-Haber Institute of the Max Planck Society, 14195 Berlin, Germany

${ }^{b}$ Department of Chemistry, Chemical and Materials Engineering Division The Electrochemical Energy, Catalysis and Materials Science LaboratoryTechnische Universität Berlin, Strasse des 17. Juni 124, 10623 Berlin (Germany)

${ }^{\mathrm{c}}$ Department of Chemistry, Technische Universität Berlin, Strasse des 17. Juni 124, 10623 Berlin (Germany)

*Corresponding author: e-mail behrens@,fhi-berlin.mpg.de, tesso@udel.edu, pstrasser@tu-berlin.de

Received 22 November 2011; Article first published online: 20 March 2012; Published June 2012

\begin{abstract}
Incipient wetness impregnation and a novel deposition symproportionation precipitation was used for the preparation of $\mathrm{MnO}_{\mathrm{x}} / \mathrm{CNT}^{\mathrm{e}}$ electrocatalysts for efficient water splitting. Nanostructured manganese oxides have been dispersed on commercial carbon nanotubes as a result of both preparation methods. A strong influence of the preparation history on the electrocatalytic performance was observed. The as-prepared state of a 6.5 wt. $-\% \mathrm{MnO}_{\mathrm{x}} / \mathrm{CNT}$ sample could be comprehensively characterized by comparison to an unsupported $\mathrm{MnO}_{\mathrm{x}}$ reference sample. Various characterization techniques revealed distinct differences in the oxidation state of the Mn centers in the as-prepared samples as a result of the two different preparation methods. As expected, the oxidation state is higher and near $+\mathrm{IV}$ for the symproportionated $\mathrm{MnO}_{\mathrm{x}}$ compared to the impregnated sample, where + II was found. In both cases an easy adjustability of the oxidation state of Mn by post-treatment of the catalysts was observed as a function of oxygen partial pressure and temperature. Similar adjustments of the oxidation state are also expected to happen under water splitting conditions. In particular, the $5 \mathrm{wt} .-\% \mathrm{MnO} / \mathrm{CNT}$ sample obtained by conventional impregnation was identified as a promising catalytic anode material for water electrolysis at neutral $\mathrm{pH}$ showing high activity and stability. Importantly, this catalytic material is comparable to state-of-art $\mathrm{MnO}_{\mathrm{x}}$ catalyst operating in strongly alkaline solutions and hence offers advantages for hydrogen production from waste and sea water under neutral, hence environmentally benign conditions.
\end{abstract}

Keywords: Oxygen evolution reaction; Manganese Oxide; Carbon Nanotubes; Electrocatalysis; Catalyst Preparation

\section{Introduction}

Electrocatalytic water splitting into hydrogen and oxygen is a key future technology for regenerative energy storage. While wind, solar photovoltaics, or hydro sources produce renewable electricity, it is generally intermittent in nature. In this context, hydrogen is a key energy carrier which can be stored either directly in molecular form or by further reversible conversion into suitable hydrogen carrier molecules [1]. The stored molecular energy of hydrogen can later be used for combustion or, more efficiently, in hydrogen fuel cells [2].

Efficient water splitting requires active and durable electrocatalysts, which minimize the required excess electrode potential (overpotentials) of both the oxygen evolution reaction (OER) and the hydrogen evolution reaction (HER) [3]. In particular, OER catalysts with suitable activi- ty and stability represent a major technical challenge due to the highly oxidizing conditions at the oxygen evolution electrode [4,5]. In current (acidic) PEM electrolyzer technology, Ti-supported $\mathrm{TiO}_{2}-\mathrm{IrO}_{2}-$ or $\mathrm{TiO}_{2}-\mathrm{RuO}_{2}$-based mixed metal oxide systems are used as dimensionally stable anodes (DSA) [3,6], while Pt is employed as cathode material. To allow a wide-spread application of OER catalysts at an affordable cost, these systems should contain minimal or no rare or noble metals. Finally, the electrocatalyst should possess a high surface-to-bulk ratio to minimize the current densities and the amount of deployed metal, and they must exhibit sufficient electronic conductivity to minimize ohmic losses.

Noble metal-free cobalt oxide-based water splitting electrocatalysts in near neutral phosphate electrolytes have been described in literature since the 1960 s as a possible replacement for the expensive and rare materials at the anode of water electrolyzers $[7,8]$, and were recently high- 
lighted in form of a self-healing electrodeposited amorphous Co oxide film [9]. However, even cobalt itself with its high technological importance for battery components is now considered as a critical raw material associated with significant supply risks for large-scale deployment $[10,11]$. As a Co replacement, Mn has attracted considerable attention. Manganese oxides play a key role as multi-valent charge storage material in electrochemical supercapacitors devices [12]. Recently electrodeposited manganese oxide films were also shown to exhibit good OER activity in strongly alkaline electrolytes [13]. From a practical point of view, however, the conventional impregnation technique with an aqueous solution containing the metal oxide precursor would be an easier and thus a more desirable catalyst preparation method than electrodeposition. Also, water splitting in neutral conditions would be more preferred over strongly alkaline ones.

Manganese oxides are known with the oxidation states $+\mathrm{II}\left(\mathrm{MnO}, \mathrm{NaCl}\right.$ structure type), +II/+III $\left(\mathrm{Mn}_{3} \mathrm{O}_{4}\right.$, tetragonally distorted or cubic spinel type), +III $\left(\mathrm{Mn}_{2} \mathrm{O}_{3}\right.$, three polymorphs), and $+\mathrm{IV}\left(\mathrm{MnO}_{2}\right.$, several polymorphs). In aqueous environment furthermore the hydroxides $\mathrm{Mn}(\mathrm{OH})_{2}$ and $\mathrm{MnOOH}$ are relevant. It is known that the oxidation states of Mn change as a function of the applied electrochemical potential [14]. $\mathrm{MnO}_{2}$ has been applied as cathode materials for the electrochemical oxygen reduction reaction (ORR) in alkaline solutions $[15,16]$, where the activity was found to strongly depend on the $\mathrm{MnO}_{2}$ polymorph [17]. With $\mathrm{Pb}$ as additive, $\mathrm{MnO}_{2}$ was also used as anodic OER catalyst in acidic environment [18]. A mixture of $\beta-\mathrm{MnO}_{2}$ and $\alpha-\mathrm{Mn}_{2} \mathrm{O}_{3}$ was found to show higher OER activities than a pure $\beta-\mathrm{MnO}_{2}$ electrode [19]. Bulk- $\mathrm{MnO}_{\mathrm{x}}$ materials may suffer from low conductivity, but were shown to work in form of thin films deposited on conductive substrates [13] or as composites mixed with low amounts of carbon to improve conductivity [20,21]. Supported nanostructured $\mathrm{MnO}_{\mathrm{x}}$ clusters [22] and $\mathrm{MnO}_{\mathrm{x}}$ nanorods [23] have also been applied as OER catalysts in neutral or alkaline solutions.

In this work, we have studied the potential of $\mathrm{MnO}_{\mathrm{x}} /$ carbon composites with a low relative amount of $\mathrm{MnO}_{\mathrm{x}}$ using two typical preparation techniques used for the synthesis of heterogeneous gas phase catalysts, namely deposition-precipitation and impregnation from aqueous solutions. These techniques are well-established, cheap and scalable and lead to typical loadings of a few weight percent of the active component. Such low loadings enable a high dispersion of the transition metal oxide and, thus, an efficient use due to a high surface-to-bulk ratio. Nanostructuring may furthermore lead to an improvement of the intrinsic catalytic properties of electrodes as defects and strain are known to enhance the performance of watersplitting electrodes [24-30]. For $\alpha-\mathrm{MnO}_{2}$ it was reported that the ORR activity increases if the electrode material is applied in a nanostructured form [Error! Bookmark not defined.17].
Regarding the carbon support, we have chosen carbon nanotubes (CNTs). CNTs have been shown to be powerful supports for electrochemical applications [20,31-34]. Due to their unique structural properties [35], they possess electronic conductivity, a high specific surface area, and tunable functional groups for a defined interaction with the precursor complex of the active component. The recent development of highly active CVD catalysts for the CNT formation process [36-38] has made this material cheap and abundant. CNTs are nowadays industrially produced on a growing scale [39].

For this study, we have applied two different deposition methods for $\mathrm{MnO}_{\mathrm{x}}$ on the CNTs. After functionalization of the CNTs with an oxidative treatment to create anchoring groups for the metal precursor, they were either impregnated using an aqueous $\mathrm{Mn}^{2+}$ nitrate solution, or used for a deposition symproportionation precipitation formally according to the scheme:

$3 \mathrm{Mn}^{2+}+2 \mathrm{MnO}_{4}^{-}+2 \mathrm{H}_{2} \mathrm{O} \rightarrow 5 \mathrm{MnO}_{2}+4 \mathrm{H}^{+}$

For the latter approach, $\mathrm{Mn}^{2+}$ ions have been preadsorbed on the CNTs and $\mathrm{MnO}_{4}^{-}$has been added as precipitating agent. In comparison to a conventional acid-base deposition-precipitation, the oxidation state of the metal cations changes during the symproportionation reaction. Thus, after preparation, two composite electrode materials with a different initial oxidation state of $\mathrm{Mn}$ are expected to form, $\mathrm{Mn}(\mathrm{II})$ in case of the impregnation and $\mathrm{Mn}(\mathrm{IV})$ in case of the deposition-precipitation. The oxidation state of $\mathrm{MnO}_{\mathrm{x}}$ is variable upon post-treatment of the electrode material and is expected to change under electrocatalytic conditions.

We have applied thermal analyses, X-ray diffraction (XRD), electron microscopy, nitrogen physisorption and Xray absorption fine structure measurements (XANES, NEXAFS) to characterize the products of these two preparation methods. In addition, electrocatalytic tests were carried out to investigate the effect of the preparation on the water splitting performance of the $\mathrm{MnO}_{\mathrm{x}} / \mathrm{CNT}$ materials.

\section{Results and Discussion}

Two different preparation methods were used for the synthesis of MWCNT-supported manganese oxide nanoparticles. The symproportionation of manganese(II) nitrate with potassium permanganate $\left(\mathrm{s}-\mathrm{MnO}_{\mathrm{x}} / \mathrm{MWCNT}_{\mathrm{ox}}\right)$ and the incipient wetness impregnation with manganese(II) nitrate $\left(\mathrm{i}-\mathrm{MnO}_{\mathrm{x}} / \mathrm{MWCNT}_{\mathrm{ox}}\right)$. Using the symproportionation technique allowed to prepare an analogous pure manganese oxide synthesized in the same conditions as s$\mathrm{MnO}_{\mathrm{x}} / \mathrm{MWCNT}_{\mathrm{ox}}$ but without carbon nanotubes as a reference for the active $\mathrm{MnO}_{\mathrm{x}}$ component of the composite electrode, which cannot be investigated independently in samples obtained from impregnation. It was furthermore 

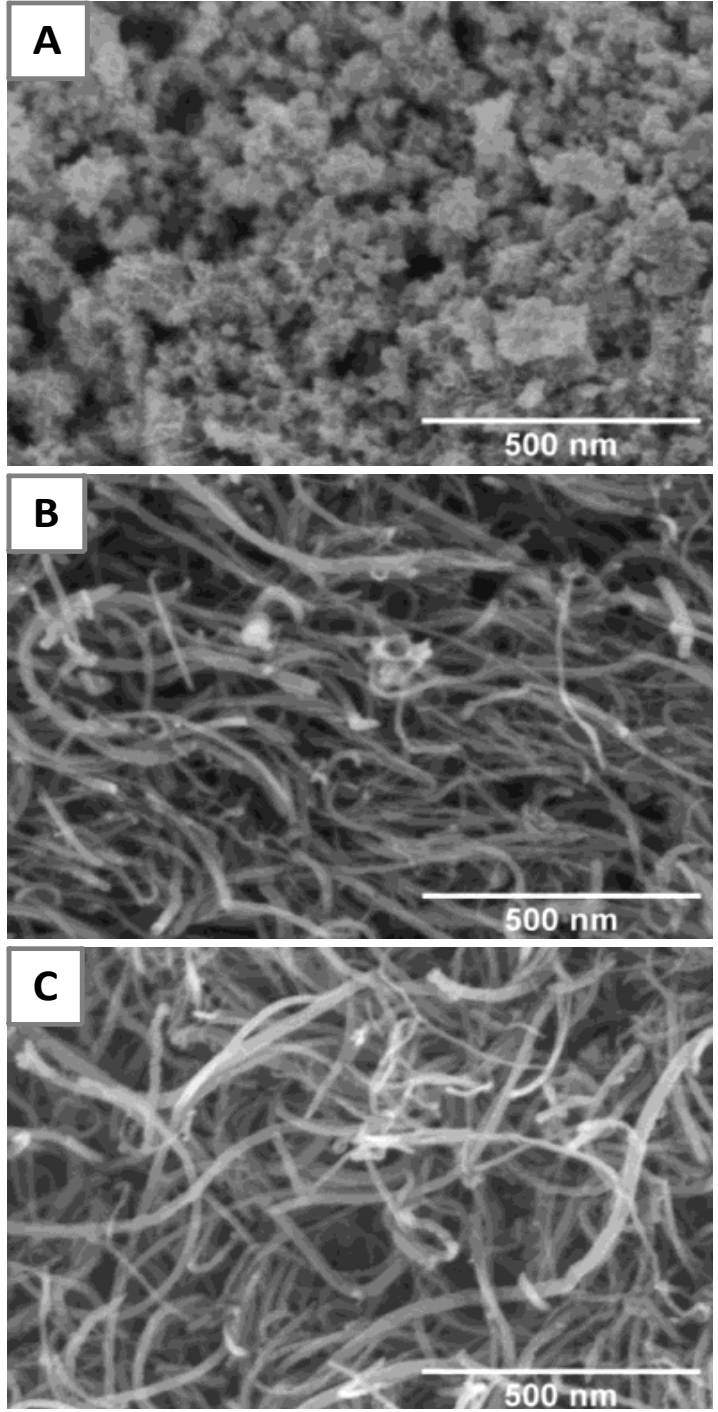

Figure 1. SEM micrographs of: $s-\mathrm{MnO}_{\mathrm{x}}(\mathrm{A}), \mathrm{s}-\mathrm{MnO}_{\mathrm{x}} / \mathrm{MWCNT}_{\mathrm{ox}}$ (B), $\mathrm{i}-\mathrm{MnO}_{\mathrm{x}} / \mathrm{MWCNT}_{\text {ox }}(\mathrm{C})$.

used as reference sample for easier characterization of the product of the symproportionation reaction of manga nese(II) nitrate and potassium permanganate $\left(\mathrm{s}-\mathrm{MnO}_{\mathrm{x}}\right)$. This latter sample will be discussed first.

SEM images of s- $\mathrm{MnO}_{\mathrm{x}}$ after drying at $110{ }^{\circ} \mathrm{C}$ are shown in Figure 1-A and as Supporting Information (SI) (Figure S1-A,B). It can be seen that very small particles of dimensions in the $10 \mathrm{~nm}$-range form larger aggregates exhibiting a high porosity. SEM-EDX analysis shows that the $\mathrm{Mn}: \mathrm{O}$ ratio is between 0.6 and 0.73 , thus too high for the target $\mathrm{MnO}_{2}$ compound. The specific surface area was determined by $\mathrm{N}_{2}$ physisorption according to the BET equation, and amounts to $232 \mathrm{~m}^{2} / \mathrm{g}$, which is relatively high for a transition metal oxide.

The dried precipitate was calcined at different temperatures, the XRD patterns of the resulting samples are presented as SI (Figure S2) together with the XRD pattern of the sample after heating to $700{ }^{\circ} \mathrm{C}$ in the thermobalance. Oxide phases do not crystallize until the calcination temperature has reached $550{ }^{\circ} \mathrm{C}$. The appearing reflections can

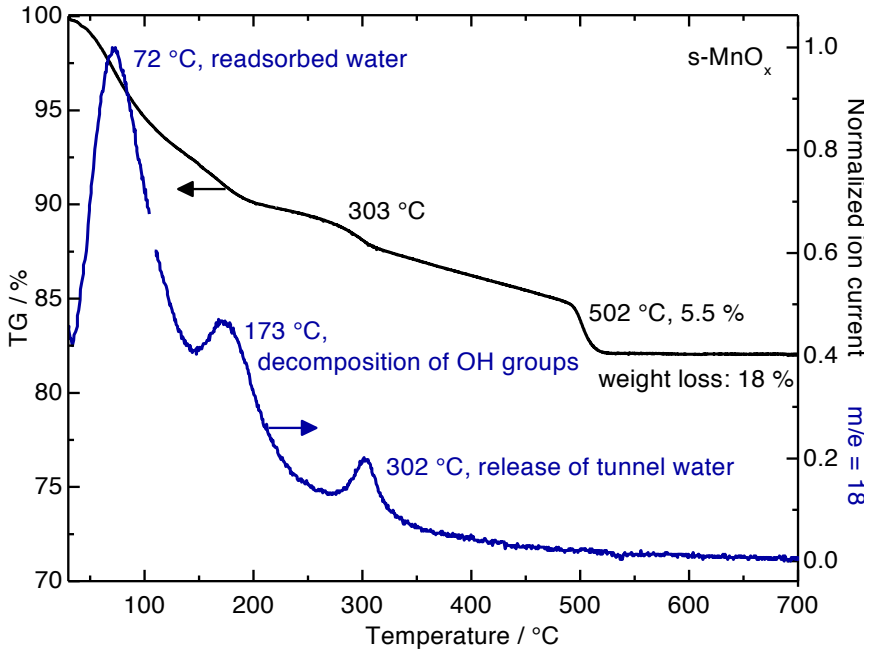

Figure 2. TG-MS curves for the thermal decomposition of manganese oxide $\left(\mathrm{s}-\mathrm{MnO}_{\mathrm{x}}\right)$ in air.

be assigned to $\mathrm{Mn}_{2} \mathrm{O}_{3}$ (Bixbyite, JCPDS 89-4836), which is in good agreement with the temperature range of the trans formation of $\mathrm{MnO}_{2}$ to $\mathrm{Mn}_{2} \mathrm{O}_{3}$ described in the literature [40]. Calcination below this temperature yields X-ray amorphous samples (Figure S2).

Simulation of the calcination by thermogravimetric measurements in synthetic air coupled with mass spectrometry is shown in Figure 2. The thermal decomposition can be divided into four major steps. Initially, at temperatures below the drying temperature of $110{ }^{\circ} \mathrm{C}$ an MS signal at $\mathrm{m} / \mathrm{e}=18$ indicated emission of weakly bonded re-absorbed water molecules. The next dehydration peak at $173{ }^{\circ} \mathrm{C}$ is assigned to the decomposition of hydroxyl groups. The small dehydration peak centered at $303{ }^{\circ} \mathrm{C}$ is assigned to emission of water, located in the $(2 \times 2)$ channels [41] of $\alpha$ $\mathrm{MnO}_{2}$, which was reported to occur near $300{ }^{\circ} \mathrm{C}$ [42]. According to the TGA data, all hydroxyl groups can be assumed as decomposed at $303{ }^{\circ} \mathrm{C}$. The mass loss observed at $502{ }^{\circ} \mathrm{C}$ is assigned to the oxygen loss due to the conversion of $\mathrm{MnO}_{2}$ to $\mathrm{Mn}_{2} \mathrm{O}_{3}$, in agreement with the XRD results. The total weight loss up to $700{ }^{\circ} \mathrm{C}$ is $18 \mathrm{wt} \%$. Assuming that at temperatures above $502{ }^{\circ} \mathrm{C}$ pure $\mathrm{Mn}_{2} \mathrm{O}_{3}$ is present, which evolved entirely from $\mathrm{MnO}_{2}$, the calculated mass difference to the state after dehydration at $303{ }^{\circ} \mathrm{C}$ should be twice as high, than the experimentally determined difference of just $5.5 \%$. This indicates that part of the manganese has been in a lower oxidation state than IV from the beginning.

The TPR profile of the sample calcined for $2 \mathrm{~h}$ at $170^{\circ} \mathrm{C}$, in which the majority of the $\mathrm{OH}$-groups should be decomposed, is shown in Figure 3. The TPR profile shows two structured peaks occurring below and above approximately $380{ }^{\circ} \mathrm{C}$. The low temperature peak has an early onset near $150{ }^{\circ} \mathrm{C}$, a shoulder to the low temperature side and a narrow peak at $267^{\circ} \mathrm{C}$. The presence of nanoparticles of manganese oxide in the sample may cause the low onset and the shoulder as dispersed manganese oxide is more 


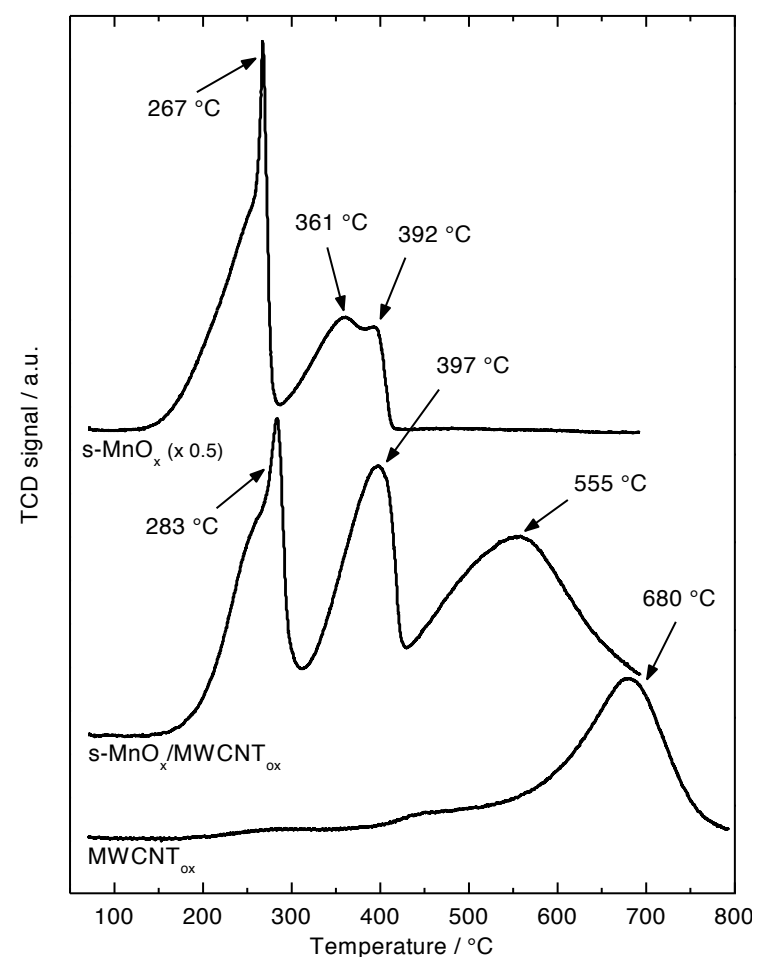

Figure 3. TPR profiles of $\mathrm{s}-\mathrm{MnO}_{\mathrm{x}}(19.0 \mathrm{mg}), \mathrm{s}-\mathrm{MnO}_{\mathrm{x}} / \mathrm{MWCNT}_{\mathrm{ox}}$ (124.8 mg) and MWCNT $_{\text {ox }}(111.5 \mathrm{mg})$.

easily reduced than bigger particles $[43,44]$. The first peak can be assigned to the reduction of $\mathrm{Mn}^{4+}$ to $\mathrm{Mn}^{3+}\left(\mathrm{MnO}_{2}\right.$ to $\mathrm{Mn}_{2} \mathrm{O}_{3}$ ). The reduction peak in the temperature range 300$400{ }^{\circ} \mathrm{C}$ is a superposition of two reduction steps. The first is assigned to the reduction of $\mathrm{Mn}_{2} \mathrm{O}_{3}$ to $\mathrm{Mn}_{3} \mathrm{O}_{4}$ and the second to that of $\mathrm{Mn}_{3} \mathrm{O}_{4}$ to $\mathrm{MnO}$ [43]. The presence of pure $\mathrm{MnO}$ after reduction at $700{ }^{\circ} \mathrm{C}$ is confirmed by XRD (not shown). Integration of the TPR curve and comparison with the reduction profile of a pure $\mathrm{CuO}$ standard reveals that the average oxidation state of manganese in the starting material is $\mathrm{Mn}^{3.42+}\left(\mathrm{MnO}_{1.71}\right)$, in agreement with the $\mathrm{Mn}: \mathrm{O}$ ratio calculated from the EDX spectra.

Further characterization of the dried sample was attempted by transmission electron microscopy investigations. As expected the sample consists of an amorphous material. The TEM micrographs in Figure 4 show, that under the reducing conditions of prolonged electron beam irradiation the material slowly crystallizes. After 13 minutes (Figure 4-C) first lattice planes can be observed, which are well pronounced after 26 minutes (Figure 4-D). The Fourier transform (FFT) of the TEM image after 26 minutes, is shown in Figure 4-E. The interplanar distances correspond to the (011) (112) (013) (121) and (220) lattice planes of tetragonal $\alpha-\mathrm{Mn}_{3} \mathrm{O}_{4}$ (Hausmannite), with lattice constants of $\mathrm{a}=5.76 \AA$ and $\mathrm{c}=9.42 \AA$. However, this result gives hardly any information about the initial oxidation state of the amorphous starting material as not only crystallization but also reduction may have been triggered by the electron beam in the microscope.
In-situ NEXAFS measurements in the total electron yield mode, which are sensitive to near-surface oxidation states, have been performed to characterize the change of the Mn valence in oxidizing conditions, i.e. with heat treatment in oxygen atmosphere. The Mn L-edges (L3-edge around $640-645 \mathrm{eV}, \mathrm{L} 2$ at $650-655 \mathrm{eV}$ ) show a rich fine structure due to a strong multiplet splitting that is very sensitive to the local chemical environment [45]. Thus, the NEXAFS is a very suitable probe for the Mn valence as it provides more evident information compared the metal $2 p$ core level spectra recorded with X-ray photoemission spectroscopy (XPS), which have to be evaluated with great care $[46,47]$. XP spectra of the samples are presented as supporting information (Fig. S8-10). The evolution of the $\mathrm{Mn}$ valence with temperature is shown in Figure 5a. Figure 6a presents the experimental and fitted NEXAFS spectra at the $\mathrm{Mn} \mathrm{L}$ absorption edges of the dried manganese oxide at room temperature and $400{ }^{\circ} \mathrm{C}$ in oxygen atmosphere ( 0.5 mbar). In agreement with the EDX, TG and TPR data, the major component in the as-prepared sample is $\mathrm{Mn}^{4+}$, but lower oxidation states are also abundant. From the NEXAFS fit an average Mn oxidation state of a hypothetically homogeneous material of +3.40 can be calculated, which is in good agreement with the TPR data. The $\mathrm{Mn}^{4+}$ component decreases with increasing temperature, while the $\mathrm{Mn}^{3+}$ component increases. The $\mathrm{Mn}^{2+}$ component is relatively stable, which may indicate that $\mathrm{Mn}^{2+}$ is not associated to the $\mathrm{Mn}^{3+}$ component in a mixed valence compound like $\mathrm{Mn}_{3} \mathrm{O}_{4}$, but that it may rather be attributed to a

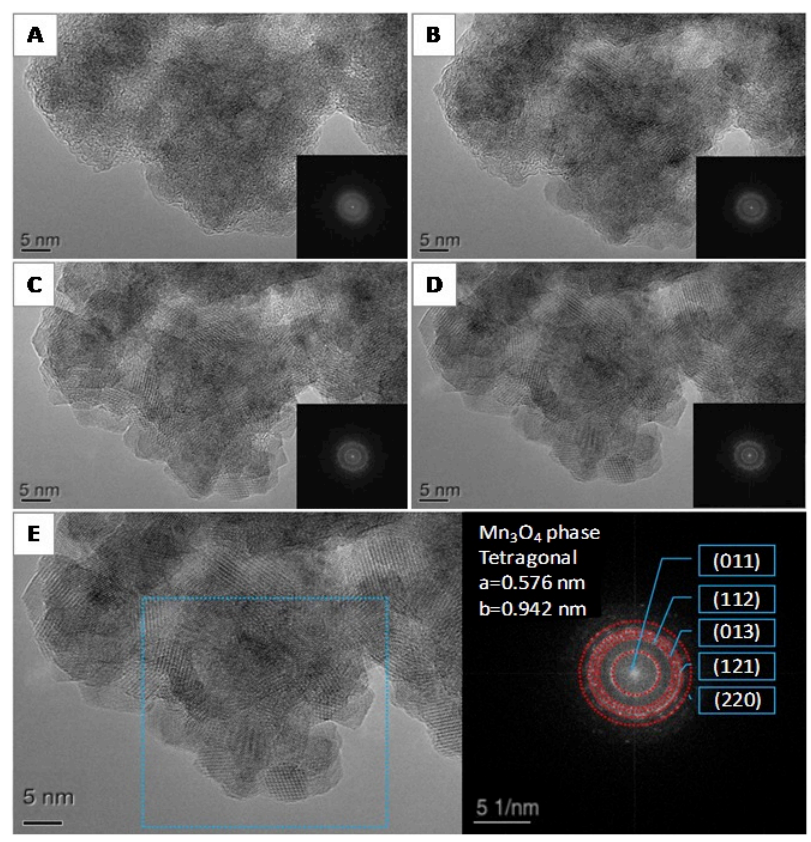

Figure 4. TEM images of the manganese oxide sample $\left(\mathrm{s}-\mathrm{MnO}_{\mathrm{x}}\right)$ under the electron beam; at the beginning (A), after 2 minutes (B), after 13 minutes (C), after 26 minutes (D) and the corresponding Fourier transform (E). 


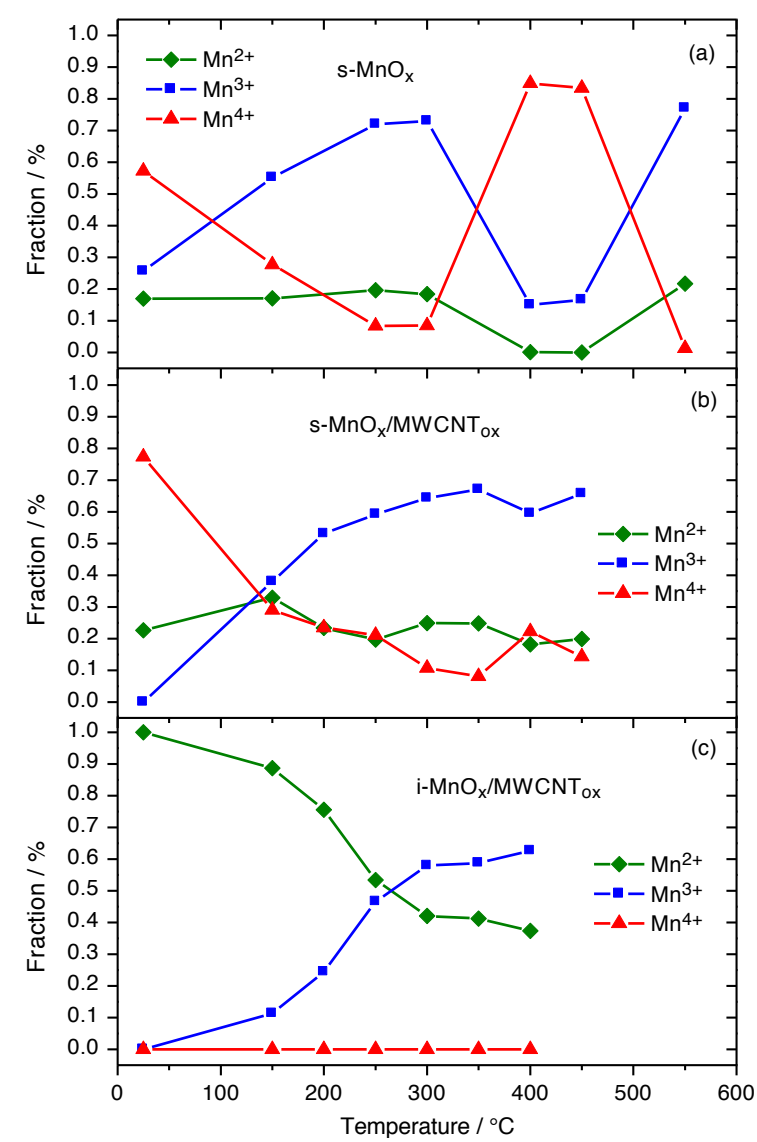

Figure 5. Evolution of the Mn species with temperature as determined by fitting of the L-NEXAFS spectra of s- $\mathrm{MnO}_{\mathrm{x}}$ in $0.5 \mathrm{mbar}$ $\mathrm{O}_{2}$ (a), s- $\mathrm{MnO}_{\mathrm{x}} / \mathrm{MWCNT}_{\mathrm{ox}}$ at 0.25 mbar $\mathrm{O}_{2}$ (b), and i$\mathrm{MnO}_{\mathrm{x}} / \mathrm{MWCNT}_{\text {ox }}$ at $0.25 \mathrm{mbar}_{2}$ (c).

surface termination in a reduced state. Between 300 and $400{ }^{\circ} \mathrm{C}$ the average reduction of the material stops after an average valence of +2.90 has been reached at $300^{\circ} \mathrm{C}$. Heating in oxygen at $400{ }^{\circ} \mathrm{C}$ results again in oxidation with an increase in the $\mathrm{Mn}^{4+}$ site fraction reaching an average oxidation state of +3.92 . At further heating above $500{ }^{\circ} \mathrm{C}$ a reduction to lower oxidation states takes place. At a temperature above $550{ }^{\circ} \mathrm{C}$, a mixture of $\mathrm{Mn}^{2+}$ and $\mathrm{Mn}^{3+}$ is existent with an average oxidation state of +2.80 . The formation of crystalline $\mathrm{Mn}_{3} \mathrm{O}_{4}$ (Hausmannite, average valence +2.67 ) at $550{ }^{\circ} \mathrm{C}$ is confirmed by XRD (not shown). It is noted that the redox chemistry of manganese oxides changes with the oxygen partial pressure and a phase barogram of the $\mathrm{Mn}-\mathrm{O}$ system was presented by $\mathrm{S}$. Fritsch et al. [40] Thus, the temperatures of thermal reduction observed at low pressure during the NEXAFS experiment are expected to be lower and cannot be directly compared to the TGA data or to the calcination in air. The intermediate formation of phase pure $\mathrm{Mn}_{2} \mathrm{O}_{3}$, which is expected when transforming $\mathrm{MnO}_{2}$ into $\mathrm{Mn}_{3} \mathrm{O}_{4}$ and which was observed in the TG experiment at $502{ }^{\circ} \mathrm{C}$ was not observed in this experiment.

Summarizing the results obtained on the sample s$\mathrm{MnO}_{\mathrm{x}}$, it can be concluded that the symproportionation of
$\mathrm{Mn}$ (II) nitrate and permanganate (VII) solutions under the given conditions yielded an amorphous hydrated manganese oxide with an average oxidation state slightly below IV $\left(\mathrm{MnO}_{1.7} \cdot \mathrm{n} \mathrm{H}_{2} \mathrm{O}\right)$. Despite the absence of a stabilizing support, the particle size of the precipitate is very small while the porosity and specific surface area are high. Upon heating in oxygen, the sample loses water and is first

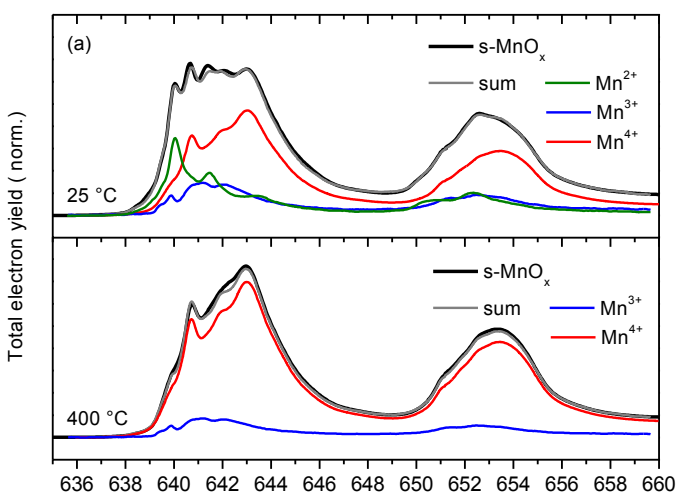
Photon energy / eV

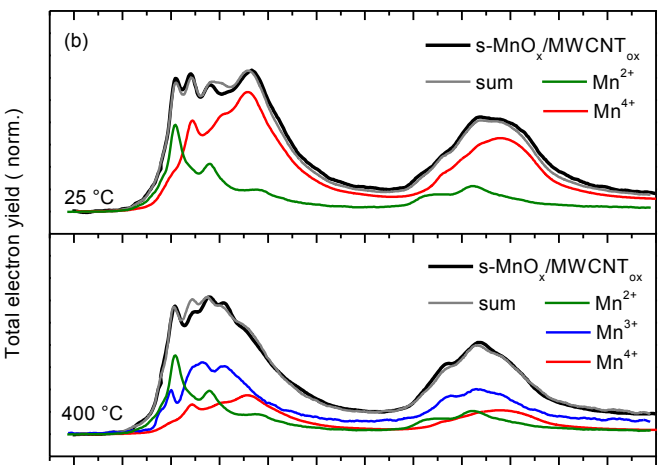

$\begin{array}{lllllllllllll}636 & 638 & 640 & 642 & 644 & 646 & 648 & 650 & 652 & 654 & 656 & 658 & 660\end{array}$ Photon energy / eV

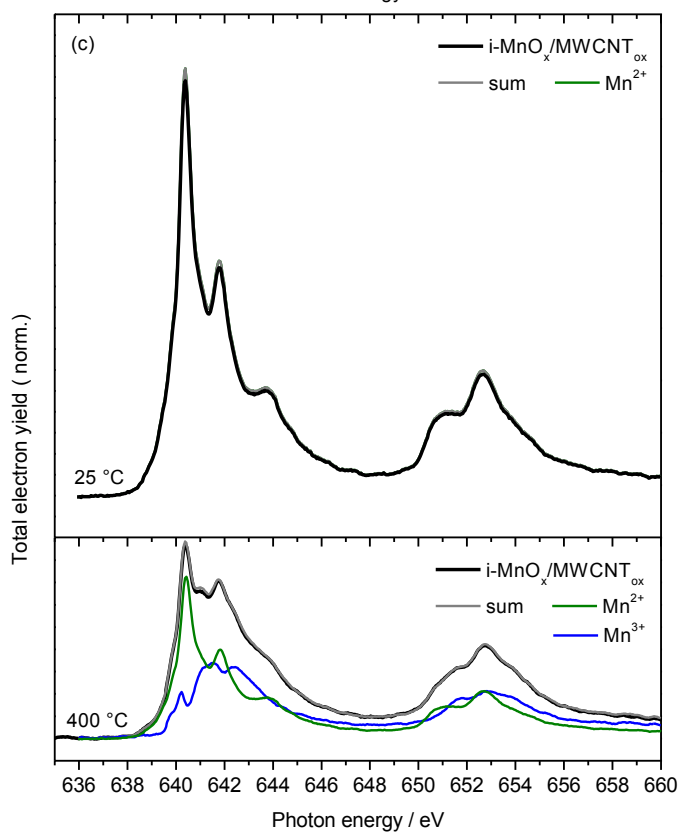

Figure 6. Mn L-NEXAFS spectra of s- $\mathrm{MnO}_{\mathrm{x}}$ in 0.5 mbar $\mathrm{O}_{2}$ (a), s$\mathrm{MnO}_{\mathrm{x}} / \mathrm{MWCNT}_{\text {ox }}$ at 0.25 mbar $\mathrm{O}_{2}(\mathrm{~b})$, and $\mathrm{i}-\mathrm{MnO}_{\mathrm{x}} / \mathrm{MWCNT}_{\mathrm{ox}}$ at $0.25 \mathrm{mbar}_{2}(\mathrm{c})$, at 25 and $400{ }^{\circ} \mathrm{C}$. 


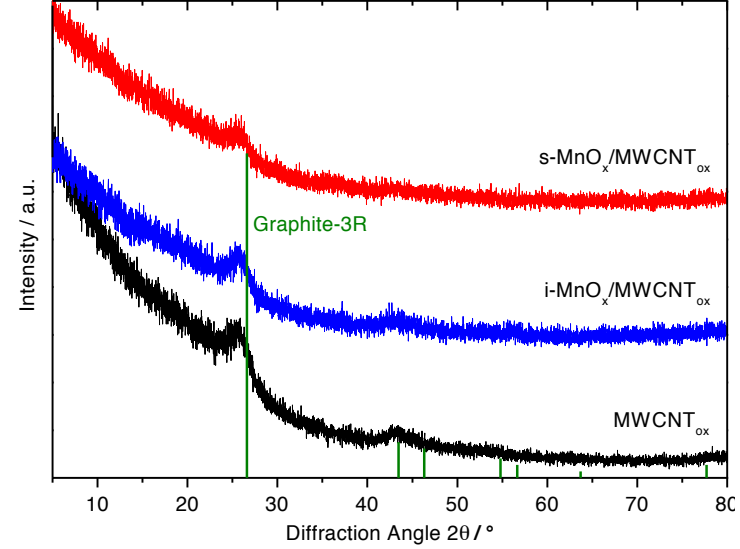

Figure 7. XRD pattern of the dried MWCNT supported manganese oxides ( $\mathrm{s}-\mathrm{MnO}_{\mathrm{x}} / \mathrm{MWCNT}_{\mathrm{ox}}$ and $\mathrm{i}-\mathrm{MnO}_{\mathrm{x}} / \mathrm{MWCNT}_{\mathrm{ox}}$ ) and oxidized MWCNTs.

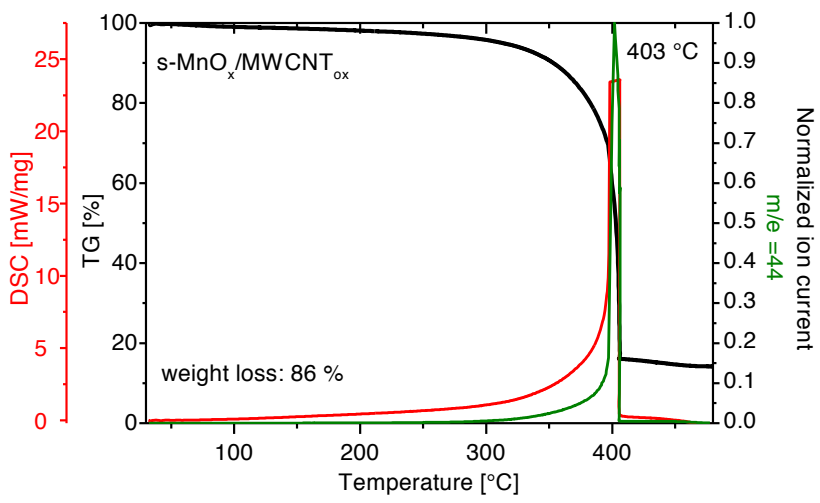

Figure 8. TG-MS-DSC curves for the thermal decomposition of manganese oxide (s-MnO$\left./ \mathrm{MWCNT}_{\mathrm{ox}}, 6.5 \mathrm{wt} \% \mathrm{Mn} / \mathrm{C}\right)$ in air.

reduced to an average oxidation state near +3 , before being oxidized to +4 around $400{ }^{\circ} \mathrm{C}$. At higher temperature, thermal reduction takes place and leads to formation of stoichiometric manganese oxides. The reactivity of the material depends on the oxygen partial pressure. In addition, TEM has shown that the material is sensitive towards electron beam irradiation, which makes the material somewhat hard to comprehensively characterize. However, the results obtained in this section will be used as reference for the supported material prepared under analogous conditions in presence of MWCNTs.

The same symproportionation reaction of manganese(II) nitrate and potassium permanganate in alkaline solution was investigated for the homogeneous deposition of manganese dioxide on the carbon nanotubes. Oxidized MWCNTs typically exhibit a negative surface charge when suspended in aqueous solutions (negative Zeta potential for $\mathrm{pH}>4$ ) due to the deprotonation of the carboxylic acid groups formed during the treatment with $\mathrm{HNO}_{3}$ [35]. Consequently, $\mathrm{Mn}^{2+}$ ions electrostatically interact and adsorb on $\mathrm{MWCNT}_{\mathrm{ox}}$, and the consecutive symproportionation reaction with $\mathrm{MnO}_{4}^{-}$is expected to take place on the sur- face on the CNTs. A s-MnO ${ }_{\mathrm{x}} / \mathrm{MWCNT}_{\mathrm{ox}}$ sample was prepared with a nominal content of $10.0 \mathrm{wt} \% \mathrm{Mn} / \mathrm{C}$ (considering that $\mathrm{Mn}$ from both $\mathrm{Mn}\left(\mathrm{NO}_{3}\right)_{2}$ and $\mathrm{KMnO}_{4}$ will be deposited on the CNTs). However, XRF analysis has shown, that the effective concentration of $\mathrm{Mn}$ in the sample amounts to only $6.5 \pm 0.5 \mathrm{wt} \% \mathrm{Mn} / \mathrm{C}$. Considering that $\mathrm{KMnO}_{4}$ is a strong oxidizing reagent, we surmise that a fraction did not react with the pre-adsorbed $\mathrm{Mn}^{2+}$ ions, but was spent to oxidize defects of carbon, which have not been completely oxidized previously by the $\mathrm{HNO}_{3}$ treatment.

The X-ray diffraction pattern of the dried manganese oxide $\left(110{ }^{\circ} \mathrm{C}\right)$, supported on MWCNTs (s$\mathrm{MnO}_{\mathrm{x}} / \mathrm{MWCNT}_{\text {ox }}$ ) with $6.5 \mathrm{wt} \% \mathrm{Mn} / \mathrm{C}$ does not show any sharp peaks (Figure 7). The intensity bumps at $2 \theta=25.6$ and $43.4^{\circ}$ correspond to the graphite of the $\mathrm{MWCNT}_{\text {ox }}$ walls. As for the unsupported reference sample, reflections of crystalline manganese oxide cannot be observed.

Calcination of the dried, $\mathrm{MWCNT}_{\text {ox }}$ supported manganese oxide was simulated by thermogravimetric measurements in synthetic air coupled with mass spectrometry. The resulting curves are shown in Figure 8. The thermal decomposition shows just one major step. Up to $300{ }^{\circ} \mathrm{C}$, no significant weight loss is observed. At $403{ }^{\circ} \mathrm{C}$ a strong mass loss is seen, caused by the total oxidation of $\mathrm{MWCNT}_{\text {ox }}$, identified by the release of large amounts of $\mathrm{CO}_{2}$ and by a sharp exothermic DTA peak. This combustion temperature, i.e. the temperature of the half weight loss in the TG curve, is significantly below the combustion temperature of pure oxidized Baytubes $\left(502{ }^{\circ} \mathrm{C}\right)$ [35], which is attributed to the dispersed $\mathrm{Mn}$ oxide phase acting as an oxidation catalyst. The total weight loss up to $480{ }^{\circ} \mathrm{C}$ is $86 \mathrm{wt} \%$. From the remaining weight of the ashes, an upper limit of the Mn loading of $8.8 \mathrm{wt} \% \mathrm{Mn} / \mathrm{C}$ can be calculated assuming $\mathrm{MnO}_{2}$ as the decomposition product. This is in reasonable agreement with the concentration determined by XRF analysis.

Although the XRD and TG results are strongly dominated by the carbon support phase, temperature programmed reduction (TPR) allows for characterization of the Mn oxide phase (Figure 3). For comparison, a TPR profile of pure $\mathrm{MWCNT}_{\text {ox }}$ was also recorded. It shows one broad peak at $680{ }^{\circ} \mathrm{C}$, due to decomposition of oxygencontaining surface groups as shown in the literature [48]. The TPR profile of the $\mathrm{s}-\mathrm{MnO}_{\mathrm{x}} / \mathrm{MWCNT}_{\mathrm{ox}}$ shows three pronounced peaks. Similar to the pure s- $\mathrm{MnO}_{\mathrm{x}}$ sample, the first peak at $283{ }^{\circ} \mathrm{C}$ is assigned to the reduction of $\mathrm{Mn}^{4+}$ to $\mathrm{Mn}^{3+}\left(\mathrm{MnO}_{2}\right.$ to $\left.\mathrm{Mn}_{2} \mathrm{O}_{3}\right)$ and possesses a shoulder to the lower temperature side. In contrast to the pure manganese oxide $\left(\mathrm{s}-\mathrm{MnO}_{\mathrm{x}}\right)$, the reduction signal assigned to $\mathrm{Mn}^{3+} \rightarrow$ $\mathrm{Mn}^{2+}$ at $397{ }^{\circ} \mathrm{C}$ does not split and the intermediate formation of $\mathrm{Mn}_{2} \mathrm{O}_{3}$ cannot be resolved. The third broad peak at $555{ }^{\circ} \mathrm{C}$ is attributed to the reduction of surface groups of the oxidized MWCNTs. Again, the increased reactivity compared to the transition metal-free system is tentatively attributed to a catalytic function of the highly dispersed $\mathrm{Mn}$ oxide during thermal treatment. The relative increase of 

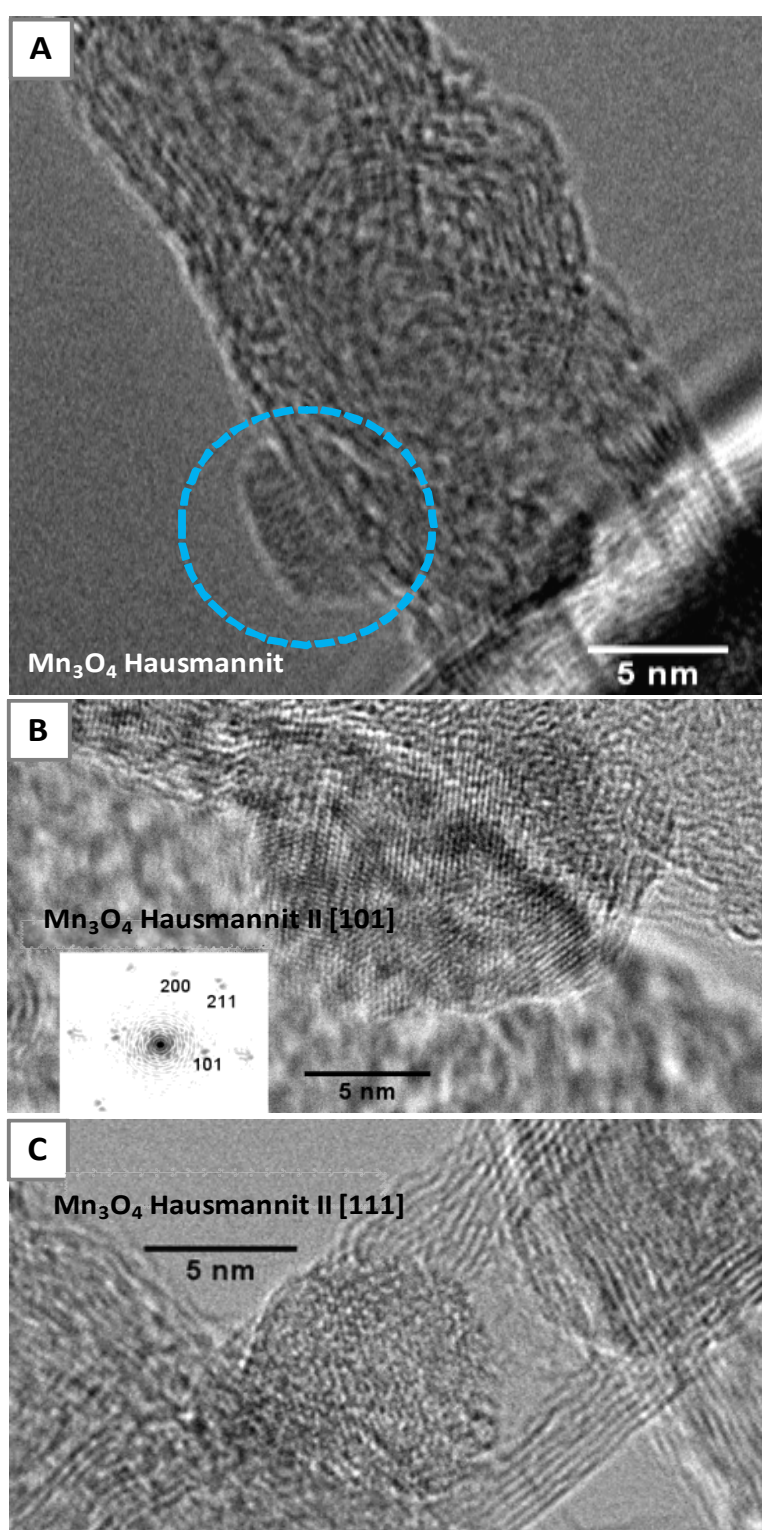

Figure 9. TEM images of $\mathrm{s}-\mathrm{MnO}_{\mathrm{x}} / \mathrm{MWCNT}_{\mathrm{ox}}$ (A) and i$\mathrm{MnO}_{\mathrm{x}} / \mathrm{MWCNT}_{\text {ox }}(\mathrm{B}, \mathrm{C})$.

this high temperature TPR signal may be explained with the creation of additional defects on the CNTs due to the presence of the strong oxidant $\mathrm{KMnO}_{4}$ during synthesis (see above). Due to the apparent similarity of the reduction temperatures and profiles of the first two TPR signals to pure manganese oxide, the Mn oxide phase in the supported sample is assumed to be identical or very similar to the s$\mathrm{MnO}_{\mathrm{x}}$ material in the unsupported case. Assuming that reduction to $\mathrm{MnO}$ is completed after the second peak, a similar average oxidation state of $\mathrm{Mn}$ in the starting material of $\mathrm{Mn}^{3.56+}\left(\mathrm{MnO}_{1.78}\right)$ can be calculated by Integration of the first two TRP signals. The presence of pure $\mathrm{MnO}$ after reduction at $700{ }^{\circ} \mathrm{C}$ is confirmed by XRD (not shown).

SEM images of the s-MnOx/MWCNT ${ }_{\text {ox }}$ after calcination at $150{ }^{\circ} \mathrm{C}$ are shown in Figure 1-B and in SI (Figure $\mathrm{S} 1-\mathrm{C}, \mathrm{D})$. Areas with large manganese agglomerates cannot be observed. In accordance with the TG-MS data, there is no damage of the MWCNTs due to starting combustion detectable even at high magnifications. SEM-EDX studies confirm that the oxidized tubes are relatively homogeneously coated with manganese oxide particles with local concentrations between 4.5 and $7.0 \mathrm{wt} \%$, in agreement with the integral XRF analysis.

The BET surface area, determined by $\mathrm{N}_{2}$ physisorption, decreased from $316 \mathrm{~m}^{2} / \mathrm{g}$ for the pure $\mathrm{MWCNT}_{\mathrm{ox}}$ to $240 \mathrm{~m}^{2} / \mathrm{g}$ after deposition of Mn oxide. The most likely explanation is that in addition to the estimated lower specific surface area of the $\mathrm{Mn}$ oxide component, $\mathrm{MnO}_{\mathrm{x}}$ particles also formed at the tubes tips as well as inside the CNTs, thus blocking the inner channel of some of the CNTs. A more detailed discussion of the physisorption data can be found as supporting information.

The TEM image of the s-MnO $\mathrm{M}_{\mathrm{x}} / \mathrm{MWCNT}$ s in Figure 9-A shows a single particle of $\mathrm{Mn}_{3} \mathrm{O}_{4}$ (Hausmannite) with a size of approximately $5 \mathrm{~nm}$. However, following the experience of pure manganese oxide it cannot be safely concluded whether the $\mathrm{Mn}_{3} \mathrm{O}_{4}$ has formed during the preparation or under the reducing conditions of the electron beam in the microscope. Nevertheless it can be assumed that the particle size would not change significantly during such beam-induced reduction, and the successful nanostructuring of the Mn oxide phase by dispersion on MWCNTs is evidenced by this result.

Further insight into the initial oxidation state of the sample $\mathrm{s}-\mathrm{MnO}_{\mathrm{x}} / \mathrm{MWCNT}_{\mathrm{ox}}$ was provided by $\mathrm{Mn} \mathrm{K}$-edge XANES (Figure 10). In contrast to the L-edge NEXAFS, $\mathrm{K}$-edge XANES is bulk sensitive. The edge position was determined to be shifted by $12.2 \mathrm{eV}$ compared to that of metallic Mn reference at $6539 \mathrm{eV}$. With respect to $\mathrm{Mn}$ oxide references such a shift is characteristic for an average valence of $\sim 3.4[49,50]$. Thus, the valence information extracted from the Mn K-edge XANES is well consistent with the results obtained from TPR analysis.

The estimated depth of information in the NEXAFS experiment is here at $5-8 \mathrm{~nm}$, which is in the range of parti cle sizes observed in TEM. Although NEXAFS is a surface sensitive method, it can be assumed, that the spectra are representative for the bulk of the present nanostructured Mn-phase. Figures $5 \mathrm{~b}$ and $6 \mathrm{~b}$ present the Mn L-edge during the calcination of the $\mathrm{MWCNT}_{\text {ox }}$ supported manganese oxide in 0.25 mbar $\mathrm{O}_{2}$. In the as-prepared state, the NEXAFS spectrum can be simulated with $\mathrm{Mn}^{2+}$ and $\mathrm{Mn}^{4+}$ species. The former may be an effect of reduction in the near-surface region of the nanoparticles. In agreement with the previous results, the average oxidation state of the sample is estimated to +3.55 . Alike the bulk reference sample $\mathrm{s}-\mathrm{MnO}_{\mathrm{x}}$, the $\mathrm{Mn}^{4+}$ component firstly decreases with increasing temperature and later comes back at $400{ }^{\circ} \mathrm{C}$ at the expanse of $\mathrm{Mn}^{2+}$ and $\mathrm{Mn}^{3+}$. This intermediate oxidation is considerably weaker compared to s-MnOx and an average oxidation state of only +3.04 is reached, while it was +2.83 at $350{ }^{\circ} \mathrm{C}$ before the re-oxidation took place. At $450{ }^{\circ} \mathrm{C}$ already thermal reduction sets in and the fraction of $\mathrm{Mn}^{4+}$ 


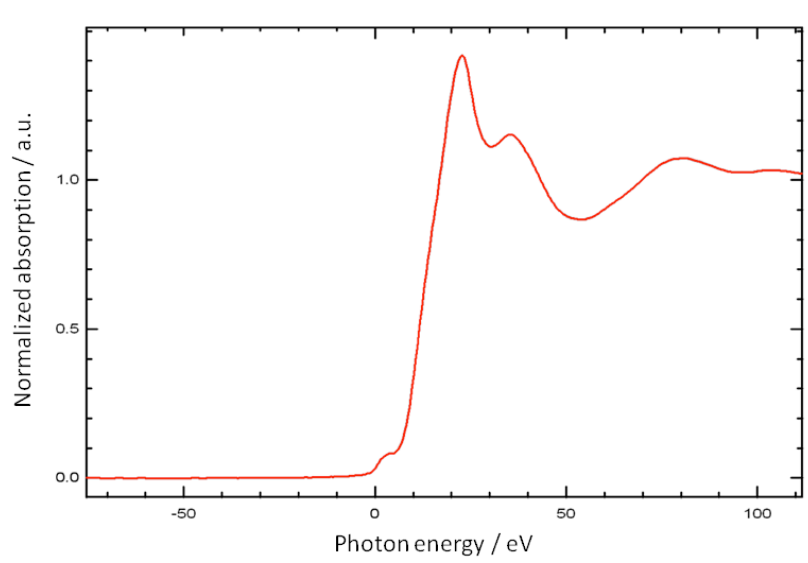

Figure 10. Mn K-XANES of as-prepared s-MnO ${ }_{x} / \mathrm{MWCNT}_{\mathrm{ox}}$. The spectrum is shown relative to the edge position of Mn metal (6539 $\mathrm{eV})$.

lowered again. The lower reaction temperature compared to $\mathrm{s}-\mathrm{MnO}_{\mathrm{x}}$ can the attributed to the smaller particle size.

The results obtained on the sample s$\mathrm{MnO}_{\mathrm{x}} / \mathrm{MWCNT}_{\text {ox }}$ show that by symproportionation it was possible to produce a nanostructured, $\mathrm{MWCNT}_{\text {ox }}$ supported manganese oxide, with similar redox properties as the unsupported manganese oxide sample s- $\mathrm{MnO}_{\mathrm{x}}$. The TPR, Kedge XANES and L-edge NEXAFS analyses show that a large part of the sample is present in the oxidation state + IV, In-situ NEXAFS measurements confirm the variability of the oxidation state of $\mathrm{Mn}$ in the electrode material with variation of the pre-treatment temperature and the oxygen partial pressure.

A third sample was prepared by incipient wetness impregnation, which is a well-known technique for catalyst preparation [51,52]. A solid catalyst support (MWCNTs) is wetted with a solution of a metal precursor. The volume of the solution is adjusted to the pore volume of the solid, so that it is just sufficient to completely fill the pores. In contrast to the symproportionation reaction, the impregnation technique is not based on a stoichiometric reaction and the phenomena occurring in the liquid phase during drying are not easily controlled on a molecular level. Nevertheless, incipient wetness impregnation is one of the most popular and most efficient techniques to deposit metal and metal oxide nanoparticles on carbon supports. It typically leads to a homogeneous metal deposition of extremely small particles [53]. Several groups studied the elementary steps involved in this transition metal deposition technique, the main contribution coming from de Jong's group. The drying and calcination of the material appear to be crucial to achieve a good dispersion. If the sample is dried at low temperature $\left(\approx 60{ }^{\circ} \mathrm{C}\right)$, that is above the melting temperature of the nitrate precursor but below its dehydration, the precursor structure is preserved and the melted compound wets and spreads over the surface of the support [54]. CNTs were shown to have a critical surface tension of $\sim 180 \mathrm{mN} \mathrm{m}^{-1}$, which allows most compounds to wet their surface [55]. In contrast, above $60-70{ }^{\circ} \mathrm{C}$, dehydration occurs and the efficiency of the impregnation depends on the chemistry of the transition metal and the mobility of the complexes which form during the decomposition of the precursor []. Recently, Munnik et al. also demonstrated that the precursor interacts and eventually reacts with the $\mathrm{OH}$ groups of the supsupport, thus leading to chemically anchored metal oxide species [57]. Several groups studied the elementary steps involved in this transition metal deposition technique, the main contribution coming from de Jong's group.

For this investigation a material with nominally $5 \mathrm{wt}$ $\% \mathrm{Mn} / \mathrm{C}$ was prepared by incipient wetness impregnation. The oxidized MWCNTs were first impregnated with water to fill their inner channel, followed by the addition of an aqueous solution of manganese(II) nitrate. The sample was dried following a 2 step process: first at $60{ }^{\circ} \mathrm{C}$ to allow the $\mathrm{Mn}$ nitrate to further spread over the surface of the sample, then at $110{ }^{\circ} \mathrm{C}$ to favor its slow dehydration and reaction with the $\mathrm{OH}$ groups present on the surface of the oxidized CNTs. Finally, the material was calcined at $300{ }^{\circ} \mathrm{C}$ to fully decompose the Mn precursor. XRD revealed that the formed $\mathrm{MnO}_{\mathrm{x}}$ was $\mathrm{X}$-ray amorphous like the other samples (Figure 7).

After calcination at $300{ }^{\circ} \mathrm{C}$, no areas with agglomerates of manganese could be found in the SEM images (Figure S1-E,F). The SEM-EDX analysis detected a local manganese concentration of $6.4 \pm 0.6 \mathrm{wt} \%$. Thus the manganese distribution is nearly homogeneous and close to the nominal $5 \mathrm{wt} \% \mathrm{Mn} / \mathrm{C}$.

The specific surface, measured by $\mathrm{N}_{2}$ physisorption, is $332 \mathrm{~m}^{2} / \mathrm{g}$ for the calcined sample $\left(300{ }^{\circ} \mathrm{C}\right)$. Thus, the $\mathrm{MWCNT}_{\text {ox }}$ surface modified with manganese oxide particles is slightly larger than the surface of pure oxidized MWCNTs $\left(316 \mathrm{~m}^{2} / \mathrm{g}\right)$, which may be explained with the starting decomposition of the carbon material. The pore size analysis (see supporting information) reveals a slightly increasing contribution corresponding to small pores in comparison to $\mathrm{MWCNT}_{\mathrm{ox}}$, which is in line with the small damages observed in the SEM images and which arise from the catalyzed oxidation of the $\mathrm{CNT}$ around the $\mathrm{MnO}_{\mathrm{x}}$ particles. Both observations point towards a different redox behavior of $\mathrm{i}-\mathrm{MnO}_{\mathrm{x}} / \mathrm{MWCNT}_{\mathrm{ox}}$ compared to s$\mathrm{MnO}_{\mathrm{x}} / \mathrm{MWCNT}_{\text {ox }}$.

Detailed transmission electron microscopy investigations of the calcined sample were performed. The TEM micrographs in Figure 9-B, C of $\mathrm{i}-\mathrm{MnO}_{\mathrm{x}} / \mathrm{MWCNT}_{\mathrm{ox}}$ shows single particles of $\mathrm{Mn}_{3} \mathrm{O}_{4}$ (Hausmannite) of approximately $5-10 \mathrm{~nm}$. However, following the experience of pure manganese oxide it again cannot be decided whether the $\mathrm{Mn}_{3} \mathrm{O}_{4}$ has formed during the preparation or under the conditions in the microscope.

The NEXAFS study of $\mathrm{i}-\mathrm{MnO}_{\mathrm{x}} / \mathrm{MWCNT}_{\text {ox }}$ (Figure 6C) shows the Mn L-edge evolution during the simulated calcination in $0.25 \mathrm{mbar}_{2}$. The as-prepared material consists exclusively of $\mathrm{Mn}^{2+}$ as is expected by impregnation with manganese(II) nitrate solution. In contrast to the s- 


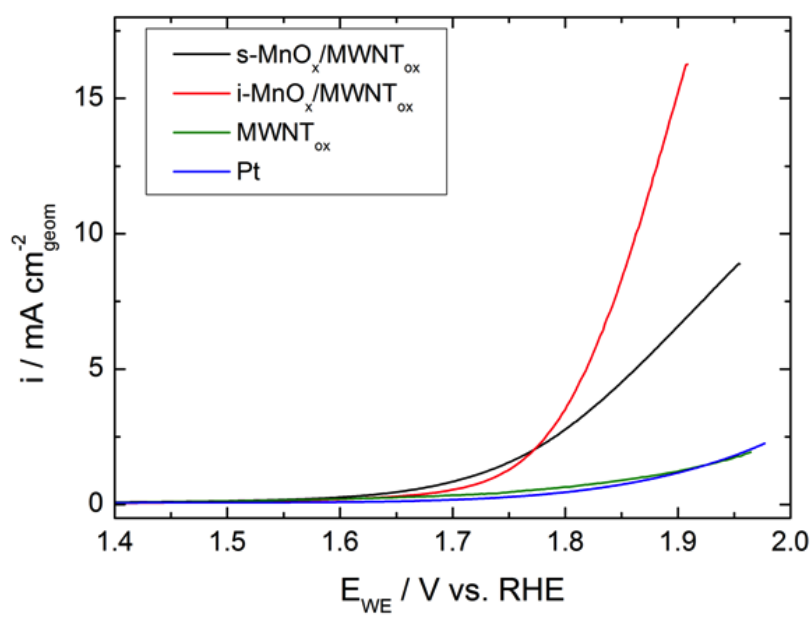

Figure 11. Electrocatalytic activity for $\mathrm{OER}$ of s-MnO $\mathrm{M}_{\mathrm{x}} / \mathrm{MWCNT}_{\mathrm{ox}}$ (black), $\mathrm{i}-\mathrm{MnO}_{\mathrm{x}} / \mathrm{MWCNT}_{\text {ox }}$ (red) and $\mathrm{MWCNT}_{\text {ox }}$ (green). Rotating disk electrode measurements has been conducted at $1600 \mathrm{rpm}$ in $0.1 \mathrm{M}$ potassium phosphate buffer at $\mathrm{pH}$ 7. Electrode potential has been sweeped between $1.0 \mathrm{~V}$ and $2.0 \mathrm{~V}$ vs. RHE with rate of $6 \mathrm{mV} / \mathrm{s}$.

$\mathrm{MnO}_{\mathrm{x}}$ samples, this sample is first oxidized upon heating and the $\mathrm{Mn}^{3+}$ component increases with increasing temperature. Heating to $400{ }^{\circ} \mathrm{C}$ results in a mixture of $\mathrm{Mn}^{2+}$ and $\mathrm{Mn}^{3+}$. The average oxidation state gradually increases from +2.0 to +2.63 at $400{ }^{\circ} \mathrm{C}$.

The Mn oxide particles obtained by incipient impregnation are of a size comparable to those prepared by symproportionation. However, from the NEXAFS results, it is evident that the oxidation state of manganese and its evolution with heat treatment is different. While in s$\mathrm{MnO}_{\mathrm{x}} / \mathrm{MWCNT}_{\text {ox }}$ a large fraction of $\mathrm{Mn}^{4+}$ was present, a divalent manganese species were exclusively found in i$\mathrm{MnO}_{\mathrm{x}} / \mathrm{MWCNT}_{\mathrm{ox}}$. While the $\mathrm{Mn}$ centers in s$\mathrm{MnO}_{\mathrm{x}} / \mathrm{MWCNT}_{\text {ox }}$ were reduced upon heating, those in i$\mathrm{MnO}_{\mathrm{x}} / \mathrm{MWCNT}_{\mathrm{ox}}$ were found to be oxidized but without the formation of $\mathrm{Mn} 4+$.

To investigate possible differences of the MWCNT support in the two supported electrode materials arising from the different preparation procedure, Raman spectroscopy and C 1s XPS was applied. The thermal analyses suggested that a higher defect concentration may have been generated by the use of strongly oxidizing $\mathrm{MnO}_{4}{ }^{-}$solution during preparation of $\mathrm{s}-\mathrm{MnO}_{\mathrm{x}} / \mathrm{MWCNT}_{\mathrm{ox}}$. Such additional defects may affect the conductive properties of the composite electrode and its electrocatalytic properties and should be reflected in the Raman [58] and carbon core level spectra [35]. No significant difference could be observed in the Raman or C 1s spectra, which are presented as supporting information (Figure S7, S11). Thus, the amount of amorphous and graphitic carbon was unchanged in the CNT support and differences in the electrocatalytic performance are likely not related to the CNT support.

Both $\mathrm{MnO}_{\mathrm{x}} / \mathrm{MWCNT}_{\text {ox }}$ nanomaterials were tested for their electrocatalytic activity and stability with respect to water splitting (oxygen evolution reaction, OER) under neutral $\mathrm{pH}$ conditions. Figure 11 compares the electrocatalytic OER activity of s- and $\mathrm{i}-\mathrm{MnO}_{\mathrm{x}} / \mathrm{MWCNT}_{\mathrm{ox}}$ during linear electrode potential sweeps at neutral $\mathrm{pH}$ with that of the carbon support and a Pt reference electrocatalyst. Both $\mathrm{MnO}_{\mathrm{x}} / \mathrm{MWCNT}_{\mathrm{ox}}$ materials showed high catalytic activity during the anodic voltammetric scans. In particular, the activity of the Mn oxide materials significantly exceeded the catalytic activity of pure Pt. The overpotential of both $\mathrm{MnO}_{\mathrm{x}} / \mathrm{MWCNT}_{\text {ox }}$ at $2 \mathrm{~mA} \mathrm{~cm} \mathrm{~cm}^{-2}$ was $190 \mathrm{mV}$ lower than for Pt. The $\mathrm{MWCNT}_{\text {ox }}$ support showed only little catalytic activity and was comparable to pure Pt. Our results demonstrate that the electrocatalytic efficiency (overpotential) of Mn-catalyzed hydrogen/oxygen production in neutral $\mathrm{pH}$ conditions of $\mathrm{pH} 7(1.8 \mathrm{~V} / \mathrm{RHE}$ at $8 \mathrm{~mA} / \mathrm{cm} 2)$ is comparable to that of the most active electrodeposited $\mathrm{MnO}_{\mathrm{x}}$ films in highly alkaline media (1.7 V/RHE) [13].

Clearly highlighted in Figure 11 are the distinct differences in the electrochemical behavior between the two manganese oxides. At a current density of $1 \mathrm{~mA} \mathrm{~cm}^{-2}$ a 20 $\mathrm{mV}$ lower overpotential was obtained for the $\mathrm{s}$ $\mathrm{MnO}_{\mathrm{x}} / \mathrm{MWCNT}_{\text {ox }}$ than $\mathrm{i}-\mathrm{MnO}_{\mathrm{x}} / \mathrm{MWCNT}_{\text {ox }}$. In contrast, at a technologically more relevant current density of $8 \mathrm{~mA} \mathrm{~cm}^{-2}$ $\mathrm{i}-\mathrm{MnO}_{\mathrm{X}} / \mathrm{MWCNT}_{\text {ox }}$ showed a $120 \mathrm{mV}$ lower overpotential than $\mathrm{s}-\mathrm{MnO}_{\mathrm{x}} / \mathrm{MWCNT}_{\mathrm{ox}}$. Thus, s-MnO $\mathrm{O}_{\mathrm{x}} / \mathrm{MWCNT}_{\mathrm{ox}}$ reveals a lower, and hence more favorably onset potential for the OER, whereas $\mathrm{i}-\mathrm{MnO}_{\mathrm{x}} / \mathrm{MWCNT}_{\mathrm{ox}}$ is catalytically more active at higher electrode potentials and current densities. Our correction for the ohmic potential drops for each catalytic measurement excludes differences in specific conductivity of the samples as origin for the

observed reactivity differences. We also note that the hypothetical faradaic current density corresponding to the conversion of all $\mathrm{Mn}$ species into the oxidation state $+\mathrm{IV}$ at the scan rate of Figure 11 would be insufficient to explain the current densities observed. Atomic-scale geometric and electronic structural factors accounting for the difference in catalytic water splitting activity may include the difference in surface area between the two supported materials (332 $\mathrm{m}^{2} / \mathrm{g}$ for i-MnO $\mathrm{M}_{\mathrm{x}}$, while $240 \mathrm{~m}^{2} / \mathrm{g}$ for the s-MnOx material); also, the presence of a lower average initial oxidation state of $\mathrm{Mn}$ between + II and + III in the i-MnOx material compared to the s-MnOx catalyst, which could be associated with structural motifs involving more hydroxyl $\mathrm{OH}$ ligands rather than Mn-bridging $\mathrm{O}$ ligand may contribute to the observed catalytic activity trends. This is consistent with earlier reports on active electrodeposited $\mathrm{MnO}_{\mathrm{x}}$, where a Mn oxidation state of +III was found predominant [13]. Based on this, we would predict that at prolonged OER relevant electrode potentials, where $\mathrm{Mn}$ is preferably present in the +IV state and would transform from the initial oxidation states, the two $\mathrm{MnO}_{\mathrm{x}}$ materials could gradually narrow their activity difference. Based on the thermodynamic Pourbaix diagram of Mn [59] we can, however, exclude the formation of $\mathrm{Mn}(+\mathrm{VII})$ species, as the applied electrode potentials are insufficient anodic.

Unlike earlier studies, the stability of the $\mathrm{MnO}_{\mathrm{x}} / \mathrm{MWCNT}_{\mathrm{ox}}$ was investigated using cyclic 


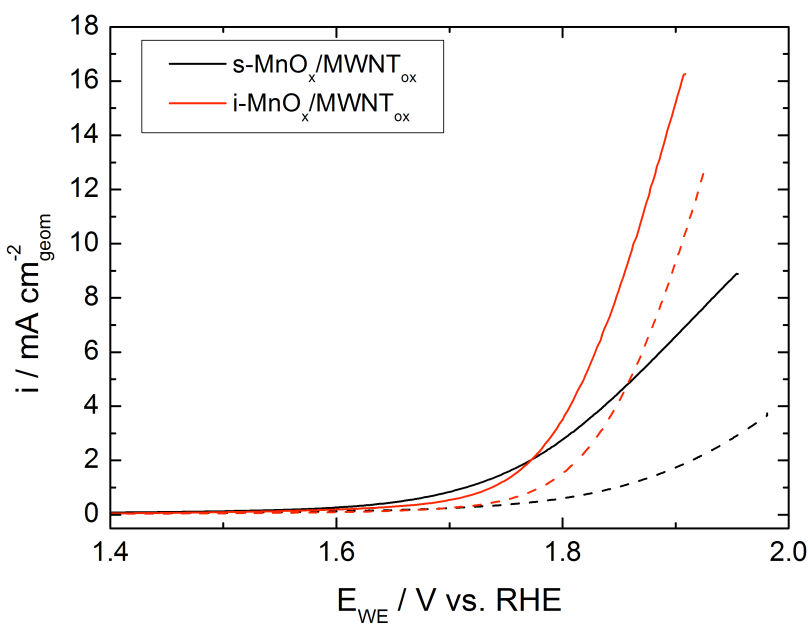

Figure 12. Electrocatalytic activity for OER of s-MnO ${ }_{\mathrm{x}} / \mathrm{MWCNT}_{\mathrm{ox}}$ (black), i-MnO ${ }_{x} / \mathrm{MWCNT}_{\text {ox }}$ (red) and $\mathrm{MWCNT}_{\text {ox }}$ (green) before (solid) and after stability test(dashed). Stability test consisted of 20 potential cycles between $1.0 \mathrm{~V}$ and $2.0 \mathrm{~V}$ vs. RHE with rate of 100 $\mathrm{mV} \mathrm{s}^{-1}$. RDE measurements has been conducted at $1600 \mathrm{rpm}$ in 0.1 $\mathrm{M}$ potassium phosphate buffer at $\mathrm{pH} 7$.

voltammetry between $1.0 \mathrm{~V}$ and $2.0 \mathrm{~V}$ and is reported in Figure 12.

The anodic linear sweep scan after 20 potential cycles led to a loss in activity for both $\mathrm{MnO}_{\mathrm{x}} / \mathrm{MWCNT}_{\mathrm{ox}}$ materials, with s-MnO${ }_{x} / \mathrm{MWCNT}_{\mathrm{ox}}$ showing a significantly higher overpotential increase (activity loss) than i$\mathrm{MnO}_{\mathrm{x}} / \mathrm{MWCNT}_{\mathrm{ox}}$. At a current density of $2 \mathrm{~mA} \mathrm{~cm}{ }^{-2}$ the overpotential for $\mathrm{s}-\mathrm{MnO}_{\mathrm{x}} / \mathrm{MWCNT}_{\mathrm{ox}}$ and i$\mathrm{MnO}_{\mathrm{x}} / \mathrm{MWCNT}_{\mathrm{ox}}$ increased by $140 \mathrm{mV}$ and $40 \mathrm{mV}$, respectively. In contrast to the $\mathrm{MnO}_{\mathrm{x}} / \mathrm{MWCNT}_{\mathrm{ox}}$, the potential cycling of $\mathrm{MWCNT}_{\mathrm{ox}}$ led to an unexpected decrease in overpotential but without exceeding the catalytic activity of the aged s-MnO${ }_{x} / \mathrm{MWCNT}_{\mathrm{ox}}$. Again, based on our current results we can only speculate on the origin of the activity degradation; e.g. loss in active surface area and hence in number of active sites or loss of the catalytically more favorable lower oxidation states (+II and +III) and associated structural motifs. The electrocatalytic stability of $\mathrm{Pt}$ is limited, owing to the formation of an insulating PtOx layer during OER which leads to additional losses caused by electron tunneling through the layer and thus, a decreased oxygen evolution activity.[60, 61]

A comparative activity study of the two $\mathrm{MnO}_{\mathrm{x}} / \mathrm{MWCNT}_{\mathrm{ox}}$ catalysts suggests of the incipient wetness material $\left(\mathrm{i}-\mathrm{MnO}_{\mathrm{x}} / \mathrm{MWCNT}_{\mathrm{ox}}\right)$ to be a viable water splitting electrocatalysts at neutral $\mathrm{pH}$. The incipient wetness preparation of supported $\mathrm{MnO}_{\mathrm{x}}$ led to more active and more stable electrocatalyst than the symproportionation preparation. The variation in catalytic activity between both catalysts can be caused by a variety of structural and electronic differences, such as oxidation states, $\mathrm{Mn}-\mathrm{O}$ bonding and bond distances, crystallinity and long range order, or variations in surface area and dispersion on the support or in support interactions between the two $\mathrm{MnO}_{\mathrm{x}}$ materials. Catalyst degradation as observed in Figure 12 can be rationalized by loss of the lower Mn oxidation states or Mn ion dissolution during oxidation-reduction cycles or the formation of inactive forms of the $\mathrm{MnO}_{2}$ species, e.g. due to changes in the crystallinity. At the moment we are far from being able to comprehensively explain the different performance of our two catalysts, but it seems clear that the preparation history and the electrochemical testing protocols of the $\mathrm{MnO}_{\mathrm{x}} / \mathrm{CNT}$ material play a crucial role for all the above mentioned properties. Further studies are necessary to unravel this fundamental structure-activity/stability interrelation between the nano-structured Mn oxide electrocatalysts. This may lead to identification of the correct "handle" among the various preparation parameters to beneficially affect the performance of $\mathrm{MnO}_{\mathrm{x}} / \mathrm{CNT}$ and allow for a knowledge-based optimization of this promising system in the future.

\section{Conclusions}

This work has demonstrated the potential of different catalyst synthesis techniques, incipient wetness impregnation and a novel deposition symproportionation precipitation, for the preparation of $\mathrm{MnO}_{\mathrm{x}} / \mathrm{CNT}$ electrocatalysts for efficient water splitting. Nanostructured manganese oxide can be dispersed on commercial carbon nanotubes by both methods and a strong influence of the preparation history on the electrocatalytic performance was observed. The asprepared state of the $6.5 \mathrm{wt} .-\% \mathrm{MnO}_{\mathrm{x}} / \mathrm{CNT}$ sample could be comprehensively characterized by comparison to an unsupported $\mathrm{MnO}_{\mathrm{x}}$ reference sample. Various characterization techniques revealed distinct differences in the oxidation state of the Mn centers in the as-prepared samples as a result of the two different preparation methods. As expected, the oxidation state is higher for the symproportionated $\mathrm{MnO}_{\mathrm{x}}$ compared to the impregnated sample. In both cases an easy adjustability of the oxidation state of $\mathrm{Mn}$ by post-treatment of the catalysts was observed as a function of oxygen partial pressure and temperature. Similar adjustments of the oxidation state are also expected to happen under water splitting conditions. In particular, the 5 wt.- $\%$ $\mathrm{MnO} / \mathrm{CNT}$ sample obtained by conventional impregnation was identified as a promising catalytic anode material for water electrolysis at neutral $\mathrm{pH}$ showing high activity and stability. Importantly, this catalytic material is comparable to state-of-art $\mathrm{MnO}_{\mathrm{x}}$ catalyst operating in strongly alkaline solutions and hence offers advantages for hydrogen production from waste and sea water under neutral, hence environmentally benign conditions. In combination with efficient photoactive semiconductors, such as $\mathrm{d}^{0}$ and $\mathrm{d}^{10}$ transition metal oxides or oxynitrides [62], this material could also become the surface electrocatalytic component in photoelectrochemical water splitting devices. 


\section{Experimental Section}

Multiwalled carbon nanotubes (MWCNTs) were supplied by Bayer MaterialScience AG Germany (Baytubes, $>95 \% \mathrm{C}$, outer diameter $15 \mathrm{~nm}$ ). Their initial specific surface area, measured by N2 adsorption (BET) is 291 $\mathrm{m} 2 / \mathrm{g}$. The pristine Baytubes were treated with concentrated nitric acid (65\% HNO3, $500 \mathrm{ml}$ for $10 \mathrm{~g} \mathrm{CNTs})$ under vigorous magnetic stirring at $100{ }^{\circ} \mathrm{C}$ for $16 \mathrm{~h}$, in order to remove the residual growth catalyst and amorphous carbon impurities and to functionalize the nanotube inner and outer surfaces by oxidation. After cooling down to room temperature, the suspension was filtered and extensively rinsed with distilled water until reaching a neutral $\mathrm{pH}$ of the filtrate. The product (MWCNTox) was dried at $110^{\circ} \mathrm{C}$ over night. The specific surface area increased from 291 to 316 $\mathrm{m} 2 / \mathrm{g}$ after a $16 \mathrm{~h}$ treatment at $100{ }^{\circ} \mathrm{C}$, most probably because part of the inner walls, which blocked the inner channel, were oxidized [35].

An unsupported manganese oxide reference sample was prepared by a symproportionation reaction in alkaline media. The $\mathrm{pH}$ of a $100 \mathrm{ml}$ solution of $0.015 \mathrm{M}$ manganese(II) nitrate tetrahydrate $\left(\mathrm{Mn}\left(\mathrm{NO}_{3}\right)_{2} \cdot 4 \mathrm{H}_{2} \mathrm{O}\right.$, Merck) and $0.09 \mathrm{M} \mathrm{NH}_{4} \mathrm{Cl}$ was adjusted to 8.0 with ammonia. $100 \mathrm{ml}$ of a $0.01 \mathrm{M}$ potassium permanganate $\left(\mathrm{KMnO}_{4}\right.$, Carl Roth) solution were added dropwise. The $\mathrm{pH}$ of the solution was kept constant at 8.0 with $\mathrm{NH}_{3}$. After filling up the volume to $500 \mathrm{ml}$ with distilled water the solution was stirred for 2 hours. Subsequently, the precipitate was filtered and washed with distilled water until the conductivity of the filtrate was $<0.5 \mathrm{mS} / \mathrm{cm}$. The product was dried for $16 \mathrm{~h}$ at $110{ }^{\circ} \mathrm{C}$ in air followed by calcination in air at various temperatures to form the manganese oxide $\left(\mathrm{s}-\mathrm{MnO}_{\mathrm{x}}\right)$.

MWCNT-supported manganese oxide was prepared using two different preparation methods, the symproportionation deposition-precipitation and incipient wetness impregnation. For the former method, the $\mathrm{pH}$ of a $100 \mathrm{ml}$ solution of $0.015 \mathrm{M}$ manganese(II) nitrate tetrahydrate $\left(\mathrm{Mn}\left(\mathrm{NO}_{3}\right)_{2} \times 4 \mathrm{H}_{2} \mathrm{O}\right.$, Merck) and $0.09 \mathrm{M} \mathrm{NH}_{4} \mathrm{Cl}$ was adjusted with ammonia to 8.0. For example, for a $10 \mathrm{wt} \%$ loading of $\mathrm{Mn}$ on MWCNT, $1.373 \mathrm{~g}$ of the oxidized CNTs $\left(\mathrm{MWCNT}_{\mathrm{ox}}\right)$ were first dispersed in $200 \mathrm{ml}$ distilled water and treated with ultrasound for a few seconds to improve dispersion. The CNT suspension was then slowly added to the $\mathrm{Mn}\left(\mathrm{NO}_{3}\right)_{2}$ solution under vigorous stirring. Finally, 100 $\mathrm{ml}$ of a $0.01 \mathrm{M}$ potassium permanganate $\left(\mathrm{KMnO}_{4}, \mathrm{ROTH}\right)$ solution were added dropwise. The $\mathrm{pH}$ of the dispersion was kept constant at 8.0 with $\mathrm{NH}_{3}$ throughout the synthesis. After filling up the volume to $500 \mathrm{ml}$ with distilled water, the solution was stirred for 2 hours at room temperature in order to allow $\mathrm{MnO}_{4}{ }^{-}$to react with $\mathrm{Mn}^{2+}$. Subsequently, the solid was filtered and washed with distilled water until the conductivity of the filtrate was $<0.5 \mathrm{mS} / \mathrm{cm}$. The product was dried for $16 \mathrm{~h}$ at $110{ }^{\circ} \mathrm{C}$ in air followed by calcination in air at various temperatures to form the MWCNTsupported manganese oxide particles $\left(\mathrm{s}-\mathrm{MnO}_{\mathrm{x}} / \mathrm{MWCNT}_{\mathrm{ox}}\right)$.
For the incipient wetness impregnation, $0.5 \mathrm{~g}$ of the oxidized Baytubes $\left(\mathrm{MWCNT}_{\mathrm{ox}}\right)$ were first impregnated with $3 \mathrm{ml}$ of distilled water in order to fill the inner channel of the CNTs and have the Mn deposition occur preferentially on the outer surface, similarly to the sample prepared by symproportionation. Two samples with a nominal loading of 5 and $10 \mathrm{wt} .-\%$ have been prepared by incipient wetness. For the $5 \mathrm{wt} \% \mathrm{Mn} / \mathrm{CNT}$ sample prepared, $114 \mathrm{mg}$ of manganese(II) nitrate tetrahydrate $\left(\mathrm{Mn}\left(\mathrm{NO}_{3}\right)_{2} \cdot 4 \mathrm{H}_{2} \mathrm{O}\right.$, Merck) were dissolved in $1 \mathrm{ml}$ of distilled water. The solution was then slowly added to the wet MWCNTs while continuously stirring the paste. The mixture was dried at $60{ }^{\circ} \mathrm{C}$ for $6 \mathrm{~h}$ and $110^{\circ} \mathrm{C}$ for $24 \mathrm{~h}$ in air. Then, it was calcined in air at different temperatures in order to decompose the manganese precursor and form MWCNT-supported manganese oxide particles (i- $\mathrm{MnO}_{\mathrm{x}} / \mathrm{MWCNT}_{\mathrm{ox}}$ ).

The X-ray powder diffraction (XRD) measurements were performed with a STOE STADI-P transmission diffractometer equipped with a focusing primary $\mathrm{Ge}(111)$ monochromator and a $3^{\circ}$ linear position sensitive detector (PSD) using $\mathrm{Cu} \mathrm{K} \alpha$ radiation. The powder samples were fixed with small amounts of X-ray amorphous grease between two thin films of polyacetate foil.

The concentration of manganese and the presence of metal impurities from the remaining catalyst were examined by wavelength dispersive X-ray fluorescence (WDXRF) using a Bruker AXS S4 PIONEER spectrometer. For this purpose, $0.5 \mathrm{~g}$ of sample was placed in a polystyrene holder ( $\varnothing 34 \mathrm{~mm}$ ) and covered with a $4 \mu \mathrm{m}$ thick polypropylene film.

Specific surface areas of the calcined material and the precursors were carried out by $\mathrm{N}_{2}$ physisorption (Quantachrome Autosorb-1) and evaluated using the BET method. The samples were outgassed for $4 \mathrm{~h}$ at $100{ }^{\circ} \mathrm{C}$. Pore size distributions were determined from the desorption branches of the isotherms using the BJH method.

The thermogravimetric analysis (TGA) and evolved gas analysis (EGA) of the decomposition reaction were achieved with a NETZSCH STA449 thermobalance under controlled gas flow $\left(21 \% \mathrm{O}_{2}\right.$ in $\left.\mathrm{Ar}, 100 \mathrm{ml} / \mathrm{min}\right)$ connected to a quadrupole mass spectrometer (QMS200 OMNISTAR, Balzers). The measurements were performed with approximately $15 \mathrm{mg}$ sample in a temperature range of $30-700$ ${ }^{\circ} \mathrm{C}(2 \mathrm{Kpm})$.

Temperature-programmed reduction (TPR) of the samples was performed in a fixed bed reactor (TPDRO1100 , CE Instruments) in $5 \% \mathrm{H}_{2} / \mathrm{Ar}(80 \mathrm{ml} / \mathrm{min})$, with a heating rate of $6 \mathrm{Kpm}$, in a quartz tube. The $\mathrm{H}_{2}$ consumption was monitored with a thermal conductivity detector (TCD). The TCD detector was calibrated by reducing a known amount of $\mathrm{CuO}$.

For morphological studies of the materials, SEM images were acquired with a Hitachi S-4800 scanning electron microscope equipped with a field emission gun. The samples were loosely dispersed on conductive carbon tape (Plano). The SEM was operated at low accelerating voltage $(1.5 \mathrm{kV})$ for a better resolution of the surface features of the 
samples. Elemental analysis by X-ray energy dispersive spectroscopy (EDX) was carried out at $15 \mathrm{kV}$ using an EDAX detector connected to the SEM.

The microstructure of the samples was examined using a Philips CM200 transmission electron microscope (TEM) equipped with a field emission gun (FEG). The samples were dispersed in chloroform and deposited on a holey carbon film supported on a copper grid. Highresolution images were taken with a CCD camera, and selected areas were processed to obtain the power spectra (square of the Fourier transform of the image), which were used for measuring inter planar distances and angles for phase identification.

To characterized the CNT support materials after the different deposition processes, Raman spectroscopy was applied at room temperature on a LabRam spectrometer using $633 \mathrm{~nm}$ laser excitation from a $\mathrm{HeNe}$ laser, with a power of $20 \mathrm{~mW}$ at the laser output. All data were obtained with a BX40 Olympus microscope (objective 100). Acquisition times were typically $3 \cdot 180 \mathrm{~s}$. Prior to the experiments, the Raman spectrometer was calibrated using a $\mathrm{Si}$ wafer.

The near-edge X-ray absorption fine structure spectra (NEXAFS) were measured at the ISISS beamline at the BESSY II synchrotron facility of the Helmholtz-Zentrum Berlin (Germany) in the end station of the FHI-MPG. The beamline was operated with $60 \mu \mathrm{m}$ exit slit. The Total Electron Yield (TEY) spectra were obtained in continuous driving mode of the monochromator (CMM) $(0.178 \mathrm{eV} / \mathrm{s})$. For the detection of the $\mathrm{Mn} \mathrm{L}_{3,2}$-edges (transition from $\mathrm{Mn} 2 \mathrm{p}$ core level to unoccupied Mn3d state) an energy region of $660-633 \mathrm{eV}$ were measured. The measurements were performed in vacuum and in $\mathrm{O}_{2}$ with a partial pressure of $0.5 \mathrm{mbar}\left(\mathrm{s}-\mathrm{MnO}_{\mathrm{x}}\right)$ and $0.25 \mathrm{mbar}\left(\mathrm{s}-\mathrm{MnO}_{\mathrm{x}} / \mathrm{MWCNT}_{\mathrm{ox}}\right.$, $\left.\mathrm{i}-\mathrm{MnO}_{\mathrm{x}} / \mathrm{MWCNT}_{\mathrm{ox}}\right)$, while heated with a constant rate $(6$ $\mathrm{Kpm}$ ) from 25 up to $550 \mathrm{~K}$. The NEXAFS data were collected at room temperature, after each incremental increase in temperature of $50-100{ }^{\circ} \mathrm{C}$ and at the final temperature. The spectra were intensity normalized to unity at $648 \mathrm{eV}$ and analyzed by fitting them with a linear combination of spectra representing $\mathrm{Mn}^{2+}, \mathrm{Mn}^{3+}$ and $\mathrm{Mn}^{4+}$ single valence sites. The WinXAS software package was used for data evaluation [63]. All experimental spectra could be described reasonably well as a superposition of these three components, which have been extracted from the data set under the assumption, that pure $\mathrm{Mn}^{2+}$ is present in the sample impregnated with $\mathrm{Mn}\left(\mathrm{NO}_{3}\right)_{2}, \mathrm{Mn}^{3+}$ is formed upon oxidation of this sample and that no $\mathrm{Mn}^{2+}$ is present after heating the symproportionated sample to $400{ }^{\circ} \mathrm{C}$ in oxygen. In the supporting information, the resulting reference spectra are compared to those of reference Mn-oxide materials $\mathrm{MnO}$ and $\mathrm{MnO}_{2}$ and a reasonable agreement was found. Using these reference materials themselves for fitting the NEXAFS spectra, however, resulted in significantly poorer agreement, which can be explained by the contribution of the local geometry to the spectrum [44], which varies in different polymorphs of Mn-oxides and may not be repre- sentative for the prepared materials. This has also been observed in studies of other mixed valence systems [64]. Xray photoemission spectra were recorded at the same beamline and results are presented as supporting information.

For the sample s-MnO ${ }_{\mathrm{x}} / \mathrm{MWCNT}_{\mathrm{ox}}$, the Mn K-edge $\mathrm{X}$-ray absorption near edge structure was measured at HASYLAB (Hamburg, Germany) at the X1 beamline in the transmission mode. The energy scale was calibrated using a $\mathrm{Mn}$ metal foil with an edge position at $6539 \mathrm{eV}$. The edge region was evaluated using WinXAS [63] by comparing the positions of the edge features on the energy scale to literature data. The edge position was determined by fitting a modified atan step-function to the near-edge region. In this work, the acronym NEXAFS is used for spectra recorded with surface-sensitive soft X-ray measurements at the Mn L-edge, while the bulk-sensitive hard X-ray measurements at the Mn K-edge are termed XANES.

Carbon-supported s- $\mathrm{MnO}_{\mathrm{x}}$ and $\mathrm{i}-\mathrm{MnO}_{\mathrm{x}}$ with an effective loading of 6.4 and $6.1 \mathrm{wt} .-\%$, respectively (dried at 110 ${ }^{\circ} \mathrm{C}$ ) have been tested for electrocatalytic activity and stability.

Electrocatalytic measurements were conducted using a 3-electrode/electrolyte compartment. Pt gauze and a commercial reversible hydrogen electrode (RHE) was used as counter and reference electrode, respectively. 0.1 M potassium phosphate buffer $(\mathrm{pH} \mathrm{7})$ was employed as an electrolyte. Catalyst inks were prepared by mixing $5 \mathrm{mg}$ catalyst with $1.99 \mathrm{ml}$ distilled water, $500 \mu \mathrm{l}$ isopropanol and $10 \mu \mathrm{l}$ of Nafion solution ( $5 \mathrm{wt} \%$, Aldrich), followed by homogenization with a hornsonicator $(5 \mathrm{~W}, 15 \mathrm{~min})$ in a water bath. The catalyst ink $(10 \mu \mathrm{l})$ was dispersed onto glassy carbon electrodes $\left(\varnothing 5 \mathrm{~mm}, 0.196 \mathrm{~m}^{2}\right)$ and dried at $60{ }^{\circ} \mathrm{C}$ in air. The glassy carbon electrodes and Pt cylinder (ø $5 \mathrm{~mm}, 0.196 \mathrm{~m}^{2}$ ) were polished and cleaned stepwise in ultrasonic bath using water and acetone before usage. Preceding the electrochemical measurements, the electrolyte was de-aerated with $\mathrm{N}_{2}$ for at least 15 min before switching to a $\mathrm{N}_{2}$ blanketing flow during measurement. OER activities were measured using anodic linear sweep voltammetry between 1.0 and $2.0 \mathrm{~V}$ vs. RHE with a sweep rate of 6 $\mathrm{mV} / \mathrm{s}$. All potentials were IR-corrected after measurements using electrochemical impedance spectroscopy. Electrochemical stability was tested by cycling the electrode potential 20 times in the mentioned potential range with a sweep rate of $100 \mathrm{mV} \mathrm{s}^{-1}$. All potentials are referred to the reversible hydrogen electrode.

\section{Acknowledgements}

We thank Edith Kitzelmann (TG, XRD), Gisela Lorenz (BET), Achim Klein-Hoffmann (XRF), Igor Kasatkin, Lide Yao und Julian Tornow (TEM), Andreas Oesterreich (NEXAFS), Juliane Scholz (XANES) and Tobias Reier (electrochemical RDE) for their support with various characterization techniques. Helmholtz Zentrum Berlin (HZB) and HASYLAB (Hamburg) are acknowledged for the allo- 
cation of synchrotron measurement time. The staff of the HZB is acknowledged for their continual support of high pressure electron spectroscopy activities of the FHI at BESSY II. Arno Bergmann and Peter Strasser acknowledge support by the German National Cluster of Excellence in Catalysis ("unifying concepts in catalysis", UNICAT)

\section{References}

[1] R. Schlögl, ChemSusChem 2010, 3, 209-222.

[2] K. Zeng, D. Zhang, Prog. Energ. Combust. Sci. 2010, 36, 307-326.

[3] H. Dau, C. Limberg, T. Reier, M. Risch, S. Roggan, P. Strasser, ChemCatChem 2010, 2, 724-761.

[4] R. Forgie, G. Bugosh, K. C. Neyerlin, Z. Liu, Peter Strasser, Electrochem. Solid-State Lett. 2010, 13, B36-B39.

[5] K. C. Neyerlin, G. Bugosh, R. Forgie, Z. Liu, P. Strasser, J. Electrochem. Soc. 2009, 156, B363-B369.

[6] E. Ortel, T. Reier, P. Strasser, R. Kraehnert, Chem. Mater. 2011, 23, 3201-3209.

[7] P. Benson, G. W. D. Briggs, W. F. K. Wynne-Jones, Electrochim. Acta 1964, 9, 281-288.

[8] O. Suzuki, M. Takahashi, T. Fukunaga, J. Kuboyama, US Patent 3,399,966, 1968.

[9] M. W. Kanan, D. G. Nocera, Science 2008, 321, 1072-1075.

[10] Critical raw materials for the E, Report of the Ad-hoc Working Group on defining critical raw materials, European Commission 2010.

[11] Studie des IZT und ISI im Auftrag des BMWi, Schlussbericht: Rohstoffe für Zukunftstechnologien 2009.

[12] H. Y. Lee, J. B. Goodenough, J. Solid State Chem. 1999, 144, 220-223.

[13] Y. Gorlin, T. F. Jaramillo, J. Am. Chem. Soc. 2010, 132, 13612-13614.

[14] F. H. B. Lima, M. L. Calegaro, E. A. Ticianelli, Electrochim. Acta 2007, 52, 3732-3738.

[15] N. Ominde, N. Bartlett, X.-Q. Yang, D. Qu, J. Power Sources 2008, 185, 747-753.

[16] N. Ominde, N. Bartlett, X.-Q. Yang, D. Qu, J. Power Sources 2010, 195, 3984-3989.

[17] F. Cheng, Y. Su, J. Liang, Z. Tao, J. Chen, Chem. Mater. 2010, 22, 898-905.

[18] S. Schmachtel, M. Toiminen, K. Kontturi, O. Forsén, M. H. Barker, J. Appl. Electrochem. 2009, 39, 1835-1848.

[19] M. Morita, C. Iwakura, H. Tamura, Electrochim. Acta 1979, 24, 357-362.

[20] V. Khomenko, E. Raymundo-Piñero, F. Béguin, J. Power Sources 2006, 153, 183-190.

[21] G. Lv, D. Wu, R. Fu, J. Non-Cryst. Solids 2009, 355, 24612465.

[22] F. Jiao, H. Frei, Chem. Commun. 2010, 46, 2920-2922.

[23] M. S. El-Daeb, M. I. Awad, A. M. Mohammad, T. Ohsaka, Electrochem. Commun. 2007, 9, 2082-2087.

[24] M. Oezaslan, P. Strasser, J. Power Sources 2011, 196 , 52405249.

[25] P. Strasser, Rev. Chem. Eng. 2009, 25 , 255-295.

[26] P. Strasser, S. Koh, T. Anniyev, J. Greeley, K. More, C. Yu, Z. Liu, S. Kaya, D. Nordlund, H. Ogasawara, M. F. Toney, A. Nilsson, Nat. Chem. 2010, 2 , 454-460.

[27] C. Yu, S. Koh, J. E. Leisch, M. F. Toney, P. Strasser, Faraday Discuss. 2009,140, 283-296.

[28] R. Srivastava, P. Mani, N. Hahn, P. Strasser, Angew. Chem., Int. Ed. 2007, 46, 8988-8991. funded by the Deutsche Forschungsgemeinschaft and managed by the Technical University Berlin. Arno Bergmann also acknowledges financial support by the Berlin Graduate school of Natural Sciences and Engineering (BIG NSE).

[29] Z. Liu, S. Koh, C. Yu, P. Strasser, J. Electrochem. Soc. 2007, 154, B1192-B1199.

[30] S. Koh, P. Strasser, J. Am. Chem. Soc. 2007, 129, 1262412625.

[31] Hu, X. Liu, J.-O. Müller, R. Schlögl, J. Maier, D. S. Su, Angew. Chem., Int. Ed. 2009, 48 (1), 210-214.

[32] F. Hasché, M. Oezaslan, P. Strasser, Phys. Chem. Chem. Phys. 2010, 12, 15251-15258.

[33] J. Zhang, Y.-S. Hu, J.-P. Tessonnier, G. Weinberg, J. Maier, R. Schlögl, D. S. Su, Adv. Mater. 2008, 20, 1450-1455.

[34] W. Xia, X. Yin, S. Kundu, M. Sánchez, A. Birkner, C. Wöll, M. Muhler, Carbon 2011, 49, 299-305.

[35] J.-P. Tessonnier, D. Rosenthal, T. W. Hansen, C. Hess, M. E. Schuster, R. Blume, F. Girgsdies, N. Pfänder, O. Timpe, D. S. Su, R. Schlögl, Carbon 2009, 47, 1779-1798.

[36] J.-P. Tessonnier, M. Becker, W. Xia, F. Girgsdies, R. Blume, L. Yao, D. S. Su, M. Muhler, R. Schlögl, ChemCatChem 2010, 2, 1559-1561.

[37] J.-P. Tessonnier, D. S. Su, ChemSusChem 2011, 4, 824-847.

[38] M. J. Becker, W. Xia, J.-P. Tessonnier, R. Blume, L. Yao, R. Schlögl, M. Muhler, Carbon 2011, in press.

[39] Q. Zhang, J.-Q. Huang, M.-Q. Zhao, W.-Z. Qian, F. Wie, ChemSusChem 2011, 4, 864-889.

[40] S. Fritsch, A. Navrotsky, J. Am. Chem. Soc. 1996, 79, 17611768.

[41] M. M. Thackeray, Prog. Solid State Chem. 1997, 25, 1-71.

[42] D. Döbber, D. Kießling, W. Schmitz, G. Wendt, Appl. Catal., B 2004, 52, 135-143.

[43] E. R. Stobbe, B. A. de Boer, J. W. Geus, Catal. Today 1999, 47, 161-167.

[44] S. P. Cramer, F. M. F. deCroot, Y. Ma, C. T. Chen, F. Sette, C. A. Kipke, D. M. Eichhorn, M. K. Chan, W. H. Armstrong, E. Libby, G. Christou, S. Brooker, V. McKee, O. C. Mullins, J. C. Fuggle, J. Am. Chem. Soc. 1991, 113, 7937-7940.

[45] M. C. Biesinger, L. W. M. Lau, A. R. Gerson, R. St. C. Smart, Appl. Surf. Sci. 2010, 25,7 887-898.

[46] M. C. Biesinger, B. P. Payne, A. P. Grosvenor, L. W. M. Lau, A. R. Gerson, R. St. C. Smart, Appl. Surf. Sci. 2011, 257, 2717-2730.

[47] J.-P. Tessonnier, D. Rosenthal, T. W. Hansen, C. Hess, M. E. Schuster, R. Blume, F. Girgsdies, N. Pfänder, O. Timpe, D. S. Su, R. Schlögl, Carbon 2009, 47, 1779-1798.

[48] J. M. Calo, D. Cazorla-Amorós, A. Linares-Solano, M. C. Román-Martinez, C. Salinas-Martinez De Lecea, Carbon 1997, 35, 543-554.

[49] T. Ressler, J. Wong, J. Roos, I. Smith, Environ. Sci. Technol. 2000, 34, 950-958.

[50] D. A. McKeown, W. K. Kot, H. Gan, I. L. Pegg, J. NonCryst. Solids 2003, 328, 71-89.

[51] P. Serp, J. L. Figueiredo in Carbon Materials for Catalysis, Wiley-VCH, Hoboken, 2009, pp. 157-176.

[52] D. Astruc in Nanoparticles and Catalysis, Wiley-VCH, Weinheim, 2008, pp. 253-277. 
[53] P. Serp, M. Corrias, P. Kalck, Appl. Catal., A 2003, 253, 337358.

[54] T. M. Eggenhuisen, J. P. den Breejen, D. Verdoes, P. E. de Jongh, K. P. de Jong, J. Am. Chem. Soc. 2010, 132, 1831818325.

[55] E. Dujardin, T. W. Ebbesen, H. Hiura, K. Tanigaki, Science 1994, 265, 1850-1852.

[56] M. Wolters, P. Munnik, J. H. Bitter, P. E. de Jongh, K. P. de Jong, J. Phys. Chem. C 2011, 115, 3332-3339.

[57] P. Munnik, M. Wolters, A. Gabrielsson, S. D Pollington, G. Headdock, J. H. Bitter, P. E. de Jongh, K. P. de Jong, J. Phys. Chem. C 2011, 115, 14698-14706.
[58] A. Sadezky, H. Muckenhuber, H. Grothe, R. Niessner, U. Pöschl, Carbon 2005, 43, 1731-1742.

[59] M. Pourbaix in Atlas of Electrochemical Equilibria in Aqueous Solutions, Pergamon Press, Brussels, 1966, p. 286.

[60] F. E. Osterloh, Chem. Mater. 2008, 20, 35-54.

[61] T. Ressler, J. Synchrotron Rad. 1998, 5, 118-122.

[62] M. M. Grush, J. Chen, T. L. Stemmler, S. J. George, C. Y. Ralston, R. T. Stibrany, A. Gelasco, G. Christou, S. M. Gorun, J. E. Penner-Hahn, S. P. Cramer, J. Am. Chem. Soc. 1996, $118,65-69$ 